\title{
PURPOSIVE INTERPRETATION OF THE UNIFORM COMMERCIAL CODE: SOME IMPLICATIONS FOR JURISPRUDENCE
}

\author{
JULIAN B. MCDONNELI $†$
}

\section{Introduction: The Code Laboratory}

Contemporary jurisprudence is absorbed in a protracted debate concerning the dimensions of judicial discretion. Is a judge in certain difficult or "hard cases" free to legislate a solution by choosing among competing alternatives, any one of which might be acceptable, or must he always reach the one right result by uncovering and weighing the pre-existing entitlements of the disputants before him? Professor H. L. A. Hart, the established sage, leads the positivist camp in contending that judges may appropriately legislate in hard cases in which the applicability of legal rules is uncertain. $^{1}$ Professor Ronald Dworkin, the provocative challenger, urges instead a "rights thesis" under which judicial decisions, even in hard cases, "characteristically are and should be generated by principle not policy." 2

In the course of this debate considerable attention has focused on the problems of legislative interpretation. Professor Hart has illustrated his position with reference to an ordinance prohibiting

† Associate Professor of Law, University of Georgia. B.S. 1963, Spring Hill College; LL.B. 1966, University of Virginia. The author expresses his appreciation to Professors Ronald Ellington, Eric Holmes, and Ellen Jordan for their criticisms of an earlier draft of this Article.

1 H. HART, ThE CONCEPT OF LAW 200 (1961). A recent statement of Professor Hart's views is contained in Hart, American Jurisprudence Through English Eyes: The Nightmare and the Noble Dream, 11 GA. L. Rev. 969 (1977).

2 Dworkin, Hard Cases, 88 HaRv. L. Rev. 1057, 1060 (1975), reprinted in R. Dworkan, Takm Rights Seriously 81, 84 (1977) [hereinafter cited as Hard Cases]. A recent statement of Professor Dworkin's position appears in Dworkin, Seven Critics, I1 Ga. L. REv. 1201 (1977). Dworkin defines the terms "principle" and "policy" in a special way. A policy argument justifies a decision because it advances or protects "some collective goal of the community as a whole." Hard Cases, supra, at 109. An argument of principle justifies a decision "by showing that the decision respects or secures some individual or group right." Id. Policy is bound up in utility, principle in fairness. In Dworkin's view a legislative program may be justified by both types of argument. Id. Legislative interpretation remains an argument about principle, however, because it is used to determine "what rights the legislature has already created." Id. 1088 n.23. In this Article, as in the Uniform Commercial Code and its commentary, no attempt is made to utilize Dworkin's definitions. The terms "purpose" and "policy" are both used here in referring to the articulated social or legal objectives of legislation, whether those objectives involve the maximization of individual fairness or the advancement of general social utility. Many Code provisions can be defended on both grounds. 
vehicles in a public park. The general word "vehicle," he argued, must have "some standard instance in which no doubts are felt about its application." 3 For example, " "[i]f anything is a vehicle a motor-car is one." " 4 Without such standard cases, general terms "would be useless to us as a medium of communication." 5 In addition to "a core of settled meaning," there will be "a penumbra of debatable cases in which words are neither obviously applicable nor obviously ruled out." " For example, would "vehicle" as used here include bicycles, airplanes, or roller skates? 7 In applying rules to cases within the penumbra a choice must sometimes be made on the basis of extra-legal factors.

Likewise, Professor Dworkin has used legislative materials to illustrate his "rights thesis," arguing that Riggs ข. Palmer ${ }^{8}$ exemplified it. Riggs involved the judicial interpretation of New York legislation enacted to ensure that a testator's will controlled the disposition of his property. The court barred a murderer from inheriting under his victim's will, and Dworkin has quoted the rationale of Riggs with approval: "No one shall be permitted to profit by his own fraud, or to take advantage of his own wrong, or to found any claim upon his own iniquity, or to acquire property by his own crime." " Thus, the result in Riggs was mandated by this principle regarding individual equity.

Despite their differences, both Hart and Dworkin seem to limit the role of the lawmakers' purpose or objective. Hart suggested that a range of "standard" cases could be controlled by linguistic convention alone, leaving inquiry into the purpose of the legislation for problems of the "penumbra." 10 Yet Hart later admitted that even the standard "easy" case might involve ambiguities that had to be resolved in light of legislative purpose, ${ }^{11}$ an admission cloud-

3 Hart, Positivism and the Separation of Law and Morals, 71 Hanv. L. Rav. 593, 607 (1958). The same example is used in H. Hart, supra note 1, at 123.

$4 \mathrm{H}$. HART, supra note 1 , at 123.

5 Id.

6 Hart, supra note 3 , at 607 .

7 See H. HART, supra note 1, at 123.

8115 N.Y. 506, 22 N.E. 188 (1889).

9 Id. at 511, 22 N.E. at 190, quoted in Dworkin, The Model of Rules, 35 U. Chr. L. Rev. 14, 23-24 (1967).

10 Professor Lon Fuller vigorously dissented from Hart's suggestion that cases could be disposed of on the basis of linguistic convention alone. Fuller, Positivism and Fidelity to Law-A Reply to Professor Hart, 71 Harv. L. Rev. 630, 661-69 (1958).

11 The clear cases are those in which there is general agreement that they fall within the scope of a rule, and it is tempting to ascribe such agreements simply to the fact that there are necessarily such agreements in the use of the shared conventions of language. But this would be an over- 
ing the very definition of the standard case. ${ }^{12}$ Professor Dworkin approaches legislative purpose from a different direction but with similar results. Consideration of purpose is not, in Dworkin's model, preconditioned on linguistic difficulties. Even when the legislature has failed to articulate a controlling policy, the jurist is to project one, basing his decision on that policy which most "satisfactorily ties the language the legislature used to its constitutional responsibilities." 13 The controlling policy, whether articulated or projected, is limited, however, by the "canonical terms of the actual statute." 14 The legislature, in Dworkin's view, is entitled to set arbitrary limits on its adopted policy. It establishes these limits through its selection of language. Arguably, it is this linguistic constraint that preserves the rights theory. Because the language of legislation limits interpretation, legislative interpretation reduces to a determination of "what rights the legislature has already created." 15

In contrast with the views of Hart and Dworkin is the theory of legislation shared by those primarily responsible for shaping the Uniform Commercial Code. Professor Karl Llewellyn and his colleagues also fashioned themselves jurisprudes. In significant respects they produced a Code structured by the orientations of the jurisprudential movement known as American legal realism.

Central to the realist movement was a belief in the necessity for a "purposive interpretation" 16 of legal institutions. The theory of purposive interpretation is rooted in the concept of law as a means to selected social ends-a method of social engineering. It

simplification because it does not allow for the special conventions of the legal use of words, which may diverge from their common use, or for the way in which the meanings of words may be clearly controlled by reference to the purpose of a statutory enactment which itself may be either explicitly stated or generally agreed.

Hart, Problems of Philosophy of Law, in 6 The Encyclopedia of Phimosophy 264, 271 (P. Edwards ed. 1967).

12 Hart admits that it is difficult to define what makes some cases "easy" and others "hard." Id. For a discussion of the uncertain role of purpose in Hart's theory, see Soper, Legal Theory and the Obligation of a Judge: The Hart/Dworkin Dispute, 75 Mrcr. L. Rev. 473, 484-88 (1977).

13 Hard Cases, supra note 2 , at 1085-86.

14 Id. 1087.

$15 I d .1088$ n.23.

16 The label "purposive interpretation" was used by Professor Fuller in his famous exchange with Hart. Fuller, supra note 10, at 669 . Writing in a natural law tradition, Fuller employed the term to refer both to the morality required for a well-ordered society and to concrete objectives of given legislation. In its reference to the latter category of articulated social or legal objectives, Fuller's program corresponds with that of moderate realists such as Llewellyn. As used here "purposive interpretation" is defined in terms of this second type of purpose. 
seeks to define legal standards in terms of the purposes they are designed to implement. It denies that either statutory provisions or common law doctrines can be adequately understood by reference to a standard of ordinary or plain usage. Thus, the realists never tired of resurrecting Justice Holmes' famous declaration: "A word is not a crystal, transparent and unchanged, it is the skin of a living thought and may vary greatly in color and content according to the circumstances and the time in which it is used." 17

Of course, the realists did not invent the practice of construing language in light of purpose. Such an approach was recognized in Anglo-American law at least as early as Heydon's Case ${ }^{18}$ in which statutory interpretation was said to demand inquiry into the "mischief and defect for which the common law did not provide" and the "true reason" of the remedy which Parliament had adopted "to cure the disease of the commonwealth." 19 The realists' program was distinguished by the programmatic and unrestrained manner in which they sought to institutionalize this approach.

In drafting the Uniform Commercial Code they first delineated central "underlying purposes and policies" of the project as a whole. These are contained in section 1-102(2):

Underlying purposes and policies of this Act are:

(a) to simplify, clarify and modernize the law governing commercial transactions;

(b) to permit the continued expansion of commercial practices through custom, usage and agreement of the parties;

(c) to make uniform the law among the various jurisdictions. ${ }^{20}$

These goals were not casually derived. They reflect the fact that the drafters thought of the Code as remedial legislation. The Code was drawn to avoid the complexity, obsolescence, and divergent interpretations which had plagued prior uniform laws in the commercial field. In an effort to assure that these objectives were not treated as a mere preamble, the drafters directed: "This Act shall

17 Towne v. Eisner, 245 U.S. 418, 425 (1918).

1876 Eng. Rep. 637 (Ex. 1584).

19 Id. 638.

20 U.C.C. \$1-102(2). 
be liberally construed and applied to promote its underlying purposes and policies." 21

Second, and more particularly, the drafters sought to articulate the policy embodied in each provision of the Code. In so doing they acted more like judges justifying a decision than legislators declaring law by fiat. ${ }^{22}$ They defended this approach to drafting as necessary for the attainment of the Code's underlying remedial objectives. Thus, the Chief Reporter listed as his first principle of drafting technique: "The principle of the patent reason: Every provision should show its reason on its face. Every body of provisions should display on their face their organizing principle." 23 Llewellyn explained this principle in terms of the demands of rationality and the central objectives of a uniform and adaptive commercial law:

The rationale of this is that construction and application are intellectually impossible except with reference to some reason and theory of purpose and organization. Borderline, doubtful, or uncontemplated cases are inevitable. Reasonably uniform interpretation by judges of different schooling, learning and skill is tremendously furthered if the reason which guides application of the same language is the same reason in all cases. A patent reason, moreover, tremendously decreases the leeway open to the skilful advocate for persuasive distortion or misapplication of the language; it requires that any contention, to be successfully persuasive, must make some kind of sense in terms of the reason; it provides a real stimulus toward, though not an assurance of, corrective growth rather than straitjacketing of the Code by way of caselaw. ${ }^{24}$

21 Id. $\$ 1-102(1)$. For a discussion of the role of policy under the Code, see D. Knga, The New Conceptualism of the Uniform Commercial Code 8-14 (1968).

22 See Danzig, A Comment on the Jurisprudence of the Uniform Commercial Code, 27 Stan. L. Rev. 621, 632 (1975). Of course, the draftsmen of the Code who worked under the aegis of the National Conference of Commissioners on Uniform State Laws and the American Law Institute were not legislators. Nevertheless, the painstaking way in which they assembled a complete code and the comparatively summary acceptance of the final product by state legislatures, permits one to speak of the drafters as the authors of the legislation. For the most part, the legislatures simply validated the purposes and policies of the private draftsmen, transforming their recommendations into public policy. See generally J. HonNOLd, THE Law of Sales and Sales Financing 5-6 (4th ed. 1976).

23 Collection of Karl Llewellyn Papers, J, VI, I, e at 5 ( I944) (unpublished manuscript on file at University of Chicago Law School), quoted in W. Twanns, KARL LIEWELLYN AND the Rearist Movement 321-22 (1973). 
Because an objective is usually indicated in a statute itself in but a terse or suggestive manner, the drafters provided a fuller delineation of purpose in the Official Comments to individual Code sections. Although it has not been frequently noticed, the textual portion of the Comments is headed "Purposes" or "Purposes of Change." These express statements of purpose follow citations to prior uniform statutory provisions. The reader is invited to compare a particular Code provision with these earlier texts in order to understand better its remedial function.

The drafters' attempt to use the commentary to facilitate purposive construction was linked with the underlying goal of uniformity. As stated in the introductory Comment to the Code:

Uniformity throughout American jurisdictions is one of the main objectives of this Code; and that objective cannot be obtained without substantial uniformity of construction. To aid in uniform construction these Comments set forth the purpose of various provisions of this Act to promote uniformity, to aid in viewing the Act as an integrated whole, and to safeguard against misconstruction. ${ }^{25}$

A similar theme is evident in the Official Comment to section 1-102 which states:

The text of each section should be read in the light of the purpose and policy of the rule or principle in question, as also of the Act as a whole, and the application of the language should be construed narrowly or broadly, as the case may be, in conformity with the purposes and policies involved..$^{26}$

The unrestrained impetus of purpose is dramatized by the suggestions in the same Comment that courts implement "a statutory policy with liberal and useful remedies not provided in the statutory text," and disregard "a statutory limitation of remedy where the reason of the limitation does not apply." 27 The official commentary indicates that, at least at times, articulated purpose is to control statutory text in Code interpretation.

As drafting the Code gave the realists a unique opportunity to legislate purposive interpretation, so experience under the Code now provides a basis for evaluating this distinctive approach. The

25 U.C.C., Comment (1962 official version), reprinted in R. Braucher \& A. Sutherland, Commercial Transactions 1 (1968 ed.).

26 U.C.C. 1-102, Comment 1.

$2 \pi \mathrm{Id}$. 
considerable body of decisions that construe the Code include opinions unequivocally embracing purposive interpretation and others totally disregarding it. Part II of this Article explores ways in which courts have avoided purposive readings; their disregard of the realist message is contrasted with a purposive reading of the same provisions. Part III seeks to deduce from cases utilizing purposive interpretation an explanation of how the procedure works. These cases are analyzed in light of some of the insights of linguistic philosophy in order to show how reference to purpose minimizes the impact of certain features of language and draftsmanship that might otherwise distort the interpretation process. Part IV then explores the limitations of purposive interpretation. An effort is made therein to grapple with the problem caused by conflicting purposes.

Because of the way in which the Code was constructed and the nature of its subject matter, U.C.C. litigation is a special arena. Nonetheless, as will be argued, the results that can be obtained through purposive interpretation of the Code, and the limitations on that technique revealed in this special context, have an impact on the larger jurisprudential debate over judicial discretion. These jurisprudential implications will emerge throughout the development of this Article and are summarized in the Conclusion.

\section{JUdicial DisRegard OF Purpostve Interpretation- Proper and IMPRoper Methodologies}

\section{A. Retreat to "Plain Meaning"}

\section{The Farmer as Merchant}

Issues that appear simple have generated considerable controversy under the Uniform Commercial Code. Consider the widely discussed question: "Is a farmer a merchant for purposes of article 2 of the Code?" Litigation raising this question has centered on section 2-201(2), which is part of the Statute of Frauds controlling contracts involving the sale of goods. The section provides that the requirement that a contract for the sale of goods priced at $\$ 500$ or more must be in writing to be enforced is satisfied in the following circumstances:

Between merchants if within a reasonable time a writing in confirmation of the contract and sufficient against the sender is received and the party receiving it has reason to know its contents, it satisfies the requirements of subsection 
(1) against such party unless written notice of objection to its contents is given within 10 days after it is received. ${ }^{28}$

As indicated by the emphasis, this alternative is available only when both buyer and seller are merchants. Can a farmer who sells only his own produce be regarded as a merchant? Changes in markets for agricultural products have contributed to repeated litigation turning on this issue. In each instance, a merchant-buyer alleged an oral contract to purchase a farmer's crop that had been followed by a written confirmation, to which the farmer asserted a Statute of Frauds defense; in the background, market prices for the crop had risen above the price set by the alleged agreement.

Unfortunately, perhaps, an early judicial examination of the question not only arose in an agricultural state-Arkansas-but also in a case in which the factual record was deficient. In Cook Grains, Inc. $v$. Fallis, ${ }^{29}$ the Arkansas court commenced its analysis of the section 2-201(2) issue by quoting the Code's definition of "merchant" in section 2-104(1):

"Merchant" means a person who deals in goods of the kind or otherwise by his occupation holds himself out as having knowledge or skill peculiar to the practices or goods involved in the transaction or to whom such knowledge or skill may be attributed by his employment of an agent or broker or other intermediary who by his occupation holds himself out as having such knowledge or skill. ${ }^{30}$

After quoting the statutory language, and briefly reporting that the record did not indicate whether the farmer-defendant in question fit the statutory definition, ${ }^{31}$ the Cook Grains court made no further attempt to analyze that language or otherwise define the policy it sought to promote. Instead, the court turned to Words and Phrases for definitions successively of a farmer ("one devoted to the tillage of the soil" 32) and of merchants (those "who make it their living to buy and sell by a continued vivacity or frequent negotiations in the mystery of merchandise, and does not include a farmer who sells what he makes" ${ }^{33}$ ). Arguably the Arkansas court

28 Id. \$2-201(2) (emphasis supplied).

29239 Ark. 982, 395 S.W.2d 555 (1965).

$30 I d$. at 964,395 S.W.2d at 556 (quoting U.C.C. $\$ 2-104(1)$ ).

31 Id.

32 Id. (quoting 16 Words aND Phrases 402 (perm. ed. 1959) (citing Sohner v. Mason, 136 Cal. App. 2d 449, 452, 288 P.2d 616, 617 (1955))).

33239 Ark. at 965, 395 S.W.2d at 557 (quoting 27 Words AND Prrases 136 (perm. ed. 1959) (citing Dyott v. Letcher \& McKee, 29 Ky. (6 J.J. Marsh.) 542, 544-45 (1831))). 
turned to such definitions only because of the paucity of evidence in the record concerning the "merchant-like" qualities of this particular farmer; its holding was, therefore, limited to the case before it. Such an explanation is belied, however, by the court's broad statement that "[o]ur attention has been called to no case, and we have found no holding that the word farmer may be construed to mean merchant." 34 By the "plain and ordinary meaning" of the words the farmer was not a merchant; ${ }^{35}$ enforcement of the alleged contract was therefore barred by the Statute of Frauds.

What is plain and ordinary in Arkansas, however, is not necessarily so in Texas. Addressing the farmer as merchant issue in Nelson v. Union Equity Co-operative Exchange, ${ }^{36}$ the Texas Supreme Court started by criticizing the Arkansas court for referrring to an ordinary meaning of merchant when the Code specified its own definition in section 2-104(1).37 The Texas court then dissected the Code definition into four prongs:

Under that definition, a person is a "merchant" if he (l) deals in goods of the kind, or (2) by his occupation holds himself out as having knowledge or skill peculiar to the practices involved in the transaction, or (3) by his occupation holds himself out as having knowledge or skill peculiar to the goods involved in the transaction, or (4) employs an intermediary who by his occupation holds himself out as having such knowledge or skill, and that knowledge or skill may be attributed to the person whose status is in question. If the facts show that a person satisfies any of the above criteria, then we are bound to hold that person to be a merchant. ${ }^{38}$

Turning to the first of the alternative prongs, dealing in goods, the Nelson court correctly noted that the U.C.C. does not define the term "deal." In the absence of a statutory definition, the court felt free to consult Black's Law Dictionary ("to traffic; to transact

34 Id. at 964,395 S.W.2d at 556-57. Furthermore, the court defined the breadth of its holding in stating that, "There is nothing whatever in the statute indicating that the word 'merchant' should apply to a farmer when he is acting in the capacity of a farmer, and he comes within that category when he is merely trying to sell the commodities he has raised." Id. at 965, 395 S.W.2d at 557.

35 The final word of the Arkansas court on the farmer as merchant question was a quotation of the maxim: "In construing a statute its words must be given their plain and ordinary meaning." Id. at 965, 395 S.W.2d at 557 (citations omitted).

36548 S.W.2d 352 (Tex. 1977).

37 Id. 355. See text accompanying note 30 supra.

$38 \mathrm{Id}$. 
business" "39) and Ballentine's Law Dictionary ("to buy or to sell" ${ }^{40}$ ) for the "plain meaning" of this term. Under the definitions the court selected, any farmer who got his crop to market would be a merchant. ${ }^{41}$

Evidently, all farmers are merchants in Texas; ${ }^{42}$ and no farmer is a merchant next door in Arkansas. In both the Cook Grains and Nelson opinions an obvious disregard of drafting purpose contributed to the disparity of results. Both courts retreated to the most discredited of techniques, invocation of plain or dictionary usage as the final word on meaning, as an alternative to purposive interpretation. The advantage of this approach from the perspective of the Arkansas court was that it enabled the court to pursue a policy of its own: protecting farmers from the additional responsibilities imposed by article 2 of the Code on merchants. ${ }^{43}$ The advantage for the Texas court was its ability to carry a Code policy beyond the constraints imposed on that policy by the draftsmen.

Section 2-201(2) was designed to limit an inequity that arose under pre-Code law which limited the enforcement of confirming memoranda to cases in which the party charged with breach of contract had signed the memorandum. ${ }^{44}$ Under that rule a con-

39 Id. (quoting Brack's Law Dictronary 487 (4th ed. 1968)).

$40 \mathrm{Id}$. (quoting Baclentine's Law Dictionary 308 (3d ed. 1969)).

41 The Texas court did go on to hold that farmer Nelson satisfied the second and third criteria of the statutory definition of merchant, and in so doing the court focused on his knowledge of the commercial practices involved in the business of growing and selling wheat. Id. 355-57. The court's alternative holdings were consistent with a purposive reading of U.C.C. $\$ 2-201(2)$.

42 Although the Nelson decision can arguably be limited to the facts presented to the court, clearly the implications of the holding with regard to the first prong of the definition of "merchant" under U.C.C. $\$ 2-104(I)$ are as broad as the statement in the text. The dissenting justices in the Nelson opinion stated that "[ $t]$ he unfortunate result of the majority decision is . . . that every farmer in Texas is held to be a "merchant." Id. 360 (Johnson, J., dissenting). Lower courts in Texas have not interpreted the Nelson opinion as being limited to its facts. See, e.g., Gray v. Kirkland, 550 S.W.2d 410, 412 (Tex. Ct. App. 1977).

43 Other agricultural states have followed the Cook Grains decision. See, e.g., Loeb \& Co., Inc. v. Schreiner, 294 Ala. 722, 321 So. 2d 199 (1975); Decatur Coop. Ass'n v. Urban, $219 \mathrm{Kan}$. 171, 547 P.2d 323 (1976). The Urban ruling has actually been defended in student commentary on the grounds that treating farmers as merchants might cause them to abandon their vocation, thus threatening the backbone of the state's economyl 16 WASHBURN L.J. 230, 236 (1976). The manner in which the "plain meaning" rule frees a court to produce its own legislation has been repeatedly recognized by commentators criticizing this approach; indeed, this effect of the rule may explain why courts cling to it despite the strong academic consensus against the doctrine. See generally Jones, The Plain Meaning Rule and Extrinsic Aids in the Interpretation of Federal Statutes, 25 WASE. U.L.Q. 2, 5-7 (1939); Murphy, Old Maxims Never Die: The "Plain-Meaning Rule" and Statutory Interpretation in the "Modern" Federal Courts, 75 Coucur. L. Rev. 1299 (1975).

44 Llewellyn's comments to this provision when it was first formulated as $\$ 14(2)$ of the Revised Sales Act are instructive. See ALI UNIFORM REVISED SAles Acr $\$ 14$, Comment (Proposed Final Draft No. 1, 1944). 
firming memo bound its sender to an enforceable contract but left the party receiving it free to speculate on the market price. If the price declined, he could enforce the contract; if the price rose, he could assert the Statute of Frauds to bar enforcement. The Statute operated to discourage the use of confirming memos. Undoubtedly, the Texas court suspected farmer Nelson of just such speculation. In the court's judgment the need to prevent such speculation and to facilitate the execution of "forward contracts" by the oral agreement-written confirmation procedure outweighed any burden on the farmer:

[T] he burden on the "merchant" seller of grain is light; all he must do is read his mail and object within ten days to the contents of the confirmatory memorandum. On the other hand, it would be a far greater burden on merchant buyers of grain to require them to execute forward sales with farmers such as Nelson by using methods other than confirmatory memoranda. ${ }^{45}$

The flaw in this reasoning is that it does not focus on the policy contemplated by the drafters when they explicitly limited section 2-201(2) to transactions "between merchants."

How would a jurist seriously concerned about the policy reflected in this limitation determine that policy? This Article contends that, for reasons specified in Part III,,6 a purposive interpreter might appropriately analogize his task to that of a translator grappling with the text of a masterpiece of German philosophy. Such a translator would undoubtedly pour over the German text, not only analyzing each passage, but also viewing the work as a whole, to assure that he accurately conveyed the author's message. Thus, the first step in purposive interpretation is: Start with the statutory language and read it all with an eye to the underlying purpose.47 Section 2-201(2) does not apply to "merchants" but to contracts "between merchants." The phrase "between merchants" is separately defined in section 2-104(3). It embraces "any transaction with respect to which both parties are chargeable with the knowledge or skill of merchants." 48 A judicial definition of the term merchant that left courts free to ignore the knowledge and skill of the particular farmer involved would be inappropriate.

45 Nelson v. Union Equity Coop. Exch., 548 S.W.2d 352, 357-58 (Tex. 1977).

46 See text accompanying notes 13490 infra.

47 This step is modified at text accompanying notes 97-99 infra.

*8 U.C.C. \$2-104(3) (emphasis supplied). 
When the Texas court in Nelson dissected section 2-104(1) into alternative prongs it neglected to include the crucial word "otherwise" as part of its second and third prongs. ${ }^{49}$ That word implies that dealing "in goods of the kind" alone was not visualized by the draftsmen as sufficient evidence of a party's status as a merchant, but rather as one way in which a potential seller "by his occupation holds himself out as having knowledge or skill peculiar to the practices or goods involved in the transaction." 50

Having learned from close scrutiny of the statutory text that knowledge or skill was evidently important to the drafters, the purposive interpreter, following the example of a translator, might next turn to the materials in which the drafters had announced their objectives-the Comments. ${ }^{51}$ The Code was formulated with the assumption that text and Comments would be considered as a unit. ${ }^{52}$ Thus, the second step in purposive interpretation is: Look for articulation of purpose in the Official Comments. Comment 1 to section 2-104 shows that the drafters felt that certain "special and clear rules" should be applied to professionals, but not to the casual or inexperienced seller or buyer. Comment 2 painstakingly, but clearly, explains that "professional status under the definition may be based upon specialized knowledge as to the goods, specialized knowledge as to business practices, or specialized knowledge as to both," depending on the nature of the provision involved. For example, the Comment asserts that a party is to be held to the mercantile standard of good faith under section 2-103(1)(b) if he has specialized knowledge of either the goods or practices involved. But the implication of a warranty of merchantability through section 2-314 is expressly conditioned on expertise in regard to the goods themselves. The exception to the Statute of Frauds requirement expressed in section 2-201(1), along with other article 2 provisions dealing with the battle of the forms (section 2-207) and firm offers

49 Compare text accompanying note 30 supra with text accompanying note 38 supra.

50 U.C.C. $\$ 2-104(1)$.

51 See text accompanying notes 24-27 supra.

52 The appropriate weight to be given the Comments in Code interpretation has been the subject of considerable discussion. See Skilton, Some Comments on the Comments to the Uniform Commercial Code, 1966 WIs. L. Rev. 597 (1966). An obvious point, worth repeating, is that the text to the Code has been enacted by state legislatures; the Comments were not. See J. HonNoLD, supra note 22, at 12. Nonetheless, it has been acknowledged that the Comments are "the main device for articulating and explaining the policies of the Code provisions." W. Twining, supra note 23, at 326. Skilton has concluded that "study of the Comments is indispensable to a knowledge of the Code." Skilton, supra, at 631. 
(section 2-205), is premised on knowledge of such non-specialized business practices as answering mail.

By now the purposive interpreter is aware that the words "between merchants" in section 2-201(2) are part of a broader policy of imposing higher standards on professionals than nonmerchants. At this point he should have some confidence that he appreciates what the drafters sought to achieve. Nevertheless, if the purposive interpreter wants to be sure that he has captured every nuance of possible meaning he should take the additional step of examining the history of the text or the problem before him. Just as a translator of a German philosophical treatise would want to read prior drafts of his author's manuscript and become familiar with earlier discussions that served as a backdrop for the masterwork, so a jurist dedicated to effectuating legislative policy will want to follow similar procedures. Thus, the third step in purposive interpretation of the U.C.G. is: Explore how the present statutory text varies from earlier drafts of the Code and from the treatment of the same subject in pre-Code law. For example, the history of section 2-104 ${ }^{53}$ reveals the following:

1. As shown by the cross-reference to "Prior Uniform Statutory Provision" in the Comment to section 2-104 the term "merchant" was not separately defined or employed in the Uniform Sales Act or other uniform laws. Nevertheless, the Comment describes seven provisions of earlier statutes as "examples of the policy expressly provided for in this Article." 54 Only two of those provisions use an expression similar to the use of "merchant" in article 2. Under section 15(2) of the Uniform Sales Act a warranty of merchantability is imposed on sales "by description from a seller who deals in goods of that description (whether he be the grower or manufacturer or not)." "55 Under section 16(c) a similar warranty is imposed on sales by sample "[i]f the seller is a dealer in goods of that kind." 56

2. In fact, the policy of formulating certain obligations of merchants separately from those of nonmerchants through the enactment of different legal standards is new with the Uniform Commercial Code. The Anglo-American common law tradition did not treat

53 Of course the purposive interpreter should also examine the history of $\$ 2-201(2)$.

54 U.C.C. \$2-104, Comment. Those prior statutory provisions referred to are: UNIFORM SALES ACT $\$ 15(2), 15(5), 16(\mathrm{c}), 45(2), 71$; UNIFORM BILLS of LADING ACT $\$ \$ 35,37$.

55 UNTFORMI SALES ACT $\S 15(2)$ (emphasis supplied).

56 UnIFORM SALES AcT $\$ 16(\mathrm{c})$. 
merchants as a distinct class. In departing from that tradition the Code's drafters were borrowing from civil law doctrine. ${ }^{57}$ Thus, the merchant category is a distinctive feature of the U.C.C.

3. The Code policy appeared first in the draft of the Uniform Revised Sales Act prepared by Llewellyn as a pilot project for article 2 of the Code. In section 7(1) of that draft the definition of merchant was substantially identical to that in current section 2-104, except the language "who deals in goods of the kind" did not appear. ${ }^{58}$ This language crept into the November, 1951 Final Text Edition without explanation. ${ }^{59}$

4. In an elaborate note to his draft of the Uniform Revised Sales Act, Llewellyn justified a separate formulation of merchants' rules on the ground that courts had in fact treated merchants differently by manipulating such concepts as "usage of trade," "the circumstances of the case," or "on the contract, express or implied." He explained that persons were not to be classified as merchants "arbitrarily" but rather on the basis of their knowledge, and illustrated this principle with the following example:

A farmer has a small farm and apple orchard, marketing three to six hundred bushels a year. With respect to the warranty of merchantability under Section 38 he is a merchant, since his experience and position necessarily charge him with packing in full accordance with what the description means in the market, as also with the truthfulness of any labelling of his packages. But Section 20(b), which incorporates into the contract additional minor terms stated in a "confirmation," depends upon the established practice of regular merchants to attend and reply promptly to correspondence. No such practice exists among small farmers, and no material term which is adverse to such a farmer is to be incorporated into the contract on the basis of that section. His occupation does not hold him out as familiar with any practice "of the kind involved" or as having the general lnowledge or skill in that aspect of a person in trade. By contrast, a large-scale farmer who is using standard business marketing methods is with respect

57 See Corman, The Law of Sales Under the Uniform Commercial Code, in Section of Corporation, Bankang \& Business Law, ABA, Uniform Commerctal. Code HandBoor 21, 22-25 (1964); Dolan, The Merchant Class of Atticle 2: Farmers, Doctors, and Others, 1977 WASH. U.L.Q. 1 (1977).

58 Compare AlI U UTForm Revised Sales Act $\$ 7(1)$ (Proposed Draft No. 1, 1944) with U.C.C. $\$ 2-104(1)$.

59 U.C.C. $\$ 2-104$ (final text ed. 1951). 
to all the transaction concerned a person in trade and therefore a "merchant." 80

Purposive interpretation of section 2-201(2) reveals that two policies are operating in that section: first, the Code attempts to reduce inequity in the operation of the Statute of Frauds by providing that a memo that obligates the sender also binds the receiver; second, a distinct and important counterpolicy limits the first by protecting those who are unfamiliar with such mercantile practices as the seller's custom of relying on a confirming memo and the buyer's need to reply to inaccurate memos promptly and in writing. Whether a given farmer is a merchant under section 2-201(2) should, if the methods of purposive interpretation are applied, depend on his business sophistication. Several courts, without engaging in the full process of interpretation outlined above, have concluded that a farmer's status is dependent on this type of factual inquiry. ${ }^{01}$

\section{Other "Plain Meaning" Cases}

The farmer as merchant cases have by no means been the Code's only encounter with the "plain meaning" rubric. Indeed, it is difficult to imagine a more direct frustration of legislative purpose than occurred in West Side Bank v. Marine National Exchange $B a n k,{ }^{62}$ a decision concerning the time limit on the deferred posting privilege accorded by article 4 to drawee banks. ${ }^{63}$ Under deferred posting, a bank is allowed time after receipt of a check drawn on it to determine if the check is to be dishonored or paid. A provisional settlement, normally a credit to an account, is made upon receipt of the check before a decision is reached whether to pay it. The steps taken by a bank in making this determination to pay, such as checking for sufficiency of funds or stop orders, and verifying signatures, is called "posting" the item. The drawee needs time to complete this investigation, but those who have sent the check for collection are also entitled to a prompt decision without collusive footdragging by the drawee bank and its customer, the drawer of

60 ALI UNIFORM REvised SALES AcT $\$ 7$, Comment, Illustration 2 (Proposed Final Draft No. 1, 1944).

61 E.g., Continental Grain Co. v. Brown, 19 UCC ReP. 52 (W.D. Wis. 1976); Continental Grain Co. v. Harbach, 400 F. Supp. 695 (N.D. Ill. 1975); Rush Johnson Farms, Inc. v. Missouri Farmer Ass'ns, Inc., 555 S.W.2d 61 (Mo. App. 1977); see Sierens v. Clausen, 60 Ill. 2d 585, 328 N.E.2d 559 (1975). In a recent Article Professor Dolan has argued that although some farmers can be considered merchants under the Code, not all farmers are. See Dolan, supra note 57, at 14-24.

6237 Wis. 2d 661, 155 N.W.2d 587 (1968).

63 See U.C.C. \$ 4-301, Comment I. 
the check. Article 4 limits the drawee to a specified time period in which to make its decision to pay. ${ }^{64}$ The check must be dishonored before the time of "final payment," or the drawee becomes accountable for it and can no longer reverse its provisional settlement. ${ }^{6 \overline{5}}$ "Final payment," the critical time limit in the collection process, is defined in section 4-213(1) as follows:

An item is finally paid by a payor bank when the bank has done any of the following, whichever happens first:

(a) paid the item in cash; or

(b) settled for the item without reserving a right to revoke the settlement and without having such right under statute, clearing house rule or agreement; or

(c) completed the process of posting the item to the indicated account of the drawer, maker or other person to be charged therewith; or

(d) made a provisional settlement for the item and failed to revoke the settlement in the time and manner permitted by statute, clearing house rule or agreement. ${ }^{66}$

Most checks are finally paid under subsection (d) when a bank fails to reverse a provisional settlement it has made before its "midnight deadline" ${ }^{87}$ or some other time limit fixed by clearing house rule or agreement.

The Code provisions dealing with deferred posting were not thought troublesome until the advent of computerization. In computerized systems the logical order of checking a drawer's account before charging it for the item is not generally followed. Instead, under the normal pattern, all checks are first processed by the computer which marks them paid, charges the accounts of the drawers, and makes various reports concerning them, such as labeling certain checks as "large items" or "insufficient funds." A bank official armed with these reports then determines whether to pay a particular item. If a decision to dishonor is made, the computer's previous actions are reversed.

Bankers, particularly those in California, feared that the computers' reversal of mechanical and judgmental factors in the posting process could result in a judicial determination of a premature final

64 See id. \$4-213.

65 See id. $\$ 4-212(1)$.

66 Id. $\$ 4-213(1)$.

67 The "midnight deadline" for a bank is midnight on the next banking day following the banking day on which it receives the item. Id. $\$ 4-104(1)(\mathrm{h})$. 
payment under section 4-213(1)(c). In order to allay this fear, the Code's Permanent Editorial Board approved in 1962 the addition to the uniform text of a new section 4-109, defining the "process of posting." 68 It reads:

The "process of posting" means the usual procedure followed by a payor bank in determining to pay an item and in recording the payment including one or more of the following or other steps as determined by the bank:

(a) verification of any signature;

(b) ascertaining that sufficient funds are available;

(c) affixing a "paid" or other stamp;

(d) entering a charge or entry to a customer's ac-, count;

(e) correcting or reversing an entry or erroneous action with respect to the item.

This was the language that the Wisconsin court dealt with in the West Side Bank case. The check in question had been mechanically charged to the drawer's account by Marine National Exchange Bank's computer, and this action had been allowed to stand by a bookkeeper who reviewed the computer report. Thereafter, Marine received a stop-order from its customer, the drawer of the check. Marine dishonored the check before its time ran out under section 4-213(1)(d), but West Side Bank, who had presented the check to Marine for payment, claimed that Marine had finally paid it under section 4-213(I)(c). There was no doubt that the computers had caused a premature final payment before Marine had the opportunity to decide whether to pay the check. Nevertheless, the Wisconsin Supreme Court held that final payment had not occurred because section 4-109 allowed "reversing an entry." It stated:

It would appear whatever rationaliae may be offered to the contrary, and they are numerous, reason must yield to the plain meaning of the statute. No limitation is set forth in the legislation. The phrase the legislature used was "reversing an entry." Only by the most strained interpretation is it possible to glean from the face of the statute the inference that the entry must have been made in error. While the legislative intent may have been otherwise, and there is evidence that some authors prominent in the FOR THE UCC, REP. No. 2, at 80-81 (1965). 
preparation of the Code concluded that only erroneous entries were intended, yet it is not within the province of this Court to seek secondary sources of legislative intent where the meaning of the statute is plain and unambiguous. ${ }^{63}$

The court focused on the language of section 4-109(e); it neglected the relationship of this language to the provision as a whole. Correcting "an entry" is only one step which a bank may take "in determining to pay an item." In the context of the facts of West Side Bank, the word "entry" is clear; there was no doubt that the drawee bank made an entry to the drawer's account and later reversed it. The meaning of "in determining to pay an item" in section 4-109 is, however, ambiguous. Is the determination made when a bank official in fact decides to pay or when the legal time limits enacted in section 4-213(1) cause a final payment to be effectuated? ${ }^{70}$ This ambiguity is confirmed by the effect of the West Side Bank ruling. It rendered section $4-213(1)$ (c) superfluous because final payment could not occur under that provision at any time earlier than that fixed by section 4-213(1)(d). The analysis of the court did not conform to the first step of purposive interpretation: to read all of the statutory text with an eye to the underlying theme. The court also failed to follow the second step by ignoring the Comment to section 4-109 which indicates that the process of posting is complete as soon as both judgmental and mechanical acts have occurred. ${ }^{71}$ The court also violated the third step by failing to consider the underlying problem of computerization which spawned the language of section 4109 in the first instance. ${ }^{72}$

Fortunately, purposive interpretation of the Code has not always been subordinate to the "plain meaning" rule. It survived a close brush with the doctrine in Fairchild Industries $v$. Maritime

${ }^{69} 37$ Wis. $2 d$ at $669-70,155$ N.W.2d at $591-92$ (footnote omitted).

70 In fairness to the court it should be noted that this ambiguity was obscured by the failure of defendant, the drawee bank, to make timely objection to affidavits offered by West Side in which it disputed Marine's claim that its procedures included a final step of exercising a second judgment as to whether any entries should be reversed. It does not appear, however, that the affidavits established that Marine did in fact reexamine its decision to pay in all or a significant number of cases. In spite of the factual ambiguity, West Side asserted that Marine had made final payment as a matter of law even under Marine's statement of the facts. See 37 Wis. $2 \mathrm{~d}$ at 665-67, 155 N.W.2d at 589-90.

71 The process of posting "involves the two basic elements of some decision to pay and some recording of the payment." U.C.C. $\$ 4-109$, Comment.

72 For a purposive interpretation of $\$ 4-109$ that refuses to follow the West Side Bank approach, see $H$. Schultz \& Son, Inc. v. Bank of Suffolk County, 22 UCC REP. 1013 (E.D.N.Y. 1977). 
Air Service Ltd.73 The issue presented in Fairchild was whether a disclaimer of implied warranties describing the sale as "as is" was required to be conspicuous. The problem resulted from the way in which sections 2-316(2) and (3) of the Code were drafted. They read:

(2) Subject to subsection (3), to exclude or modify the implied warranty of merchantability or any part of it the language must mention merchantability and in case of a writing must be conspicuous . . . .

(3) Notwithstanding subsection (2)

(a) unless the circumstances indicate otherwise, all implied warranties are excluded by expressions like "as is", "with all faults" or other language which in common understanding calls the buyer's attention to the exclusion. of warranties and makes plain that there is no implied warranty; and

(c) an implied warranty can also be excluded or modified by course of dealing or course of performance or usage of trade. ${ }^{74}$

Three of the seven judges on Maryland's Court of Appeals felt that the issue could be resolved by simply looking to the definition of "notwithstanding" in Webster's Dictionary. When used as a preposition, "notwithstanding," according to Webster's, means "in spite of." " Accordingly, these three dissenting judges concluded that under section 2-316(3) the terms "as is" and "with all faults" could exclude implied warranties without regard to the requirement of conspicuousness stated in section 2-316(2). The dissent made no attempt to define what policy might be served by allowing "with all faults" or "as is" disclaimers to exclude warranties even when those expressions are hidden in a form contract, although other disclaimer language must be "so written that a reasonable person against whom it is to operate ought to have noticed it." 76 In so doing the opinion seems to subscribe to what has been called the "flagellant" theory of statutory construction-if the legislators' draftmanship is defective, the courts will teach them to improve by taking them literally. ${ }^{7 \pi}$

73274 Md. 181, 333 A.2d 313 (1975).

74 U.C.C. $\$ \$ 2-316(2),(3)(a),(3)$ (c) (emphasis supplied).

$75274 \mathrm{Md}$. at $191 \mathrm{n} .2,333 \mathrm{~A} .2 \mathrm{~d}$ at $319 \mathrm{n.2}$ (Singley, J., dissenting) (quoting Webster's New Internationax Dictionarx 1669 (2d ed. 1944)).

76 This is the basic definition of "conspicuous" set forth in U.C.C. $\$ 1-201(10)$.

77 H. Hart \& A. Sacks, The Legal Process: Bastc Problems in the Makine and Application of luatw 99-100 (tent. ed. 1958). 
Judge Singley, writing for the dissenters in Fairchild, stated: "In matters involving statutory construction, I follow Lord Mildew's dictum in Bluff $v$. Father Gray, 'If Parliament does not mean what it says, it must say so." " 78

Fortunately, Judge Singley was unable to convince the majority of his colleagues who exhibited a basic understanding of at least the first two steps of purposive interpretation. First, looking at the statutory text as a whole, the majority found the target of the word "notwithstanding" to be uncertain.

It is evident, of course, that the words "as is" constitute an exception to the general rule, contained in subsection (2), pertaining to an exclusion or modification of warranties, but it is not clear, as Fairchild would have us hold, that those words go so far as to obviate the conspicuousness requirement in subsection (2). In the case of an implied warranty of merchantability, subsection (2) requires use of the word "merchantability," and if in writing, that it be conspicuous. An "as is" disclaimer eliminates the requirement of the word "merchantability," but it is not clear from this language that the disclaimer, if in writing, need not be conspicuous. With respect to the exclusion of an implied warranty of fitness, subsection (2) requires that it be in writing and conspicuous, but it is unclear from subsection (3)(a) which of these requirements is dispensed with by the use of the "as is" disclaimer. ${ }^{79}$

Because of this lack of clarity, the majority was willing to glean the real legislative intent and allow it to prevail over "literal meaning." They found an unequivocal statement of purpose in Comment $I$ to section 2-316:

This section is designed principally to deal with those frequent clauses in sales contracts which seek to exclude "all warranties, express or implied." It seeks to protect a buyer from unexpected and unbargained language of disclaimer by denying effect to such language when inconsistent with language of express warranty and permitting the exclusion of implied warranties only by conspicuous language or other circumstances which protect the buyer from surprise. ${ }^{80}$

$78274 \mathrm{Md}$. at 191, $333 \mathrm{A.2d}$ at 319 (Singley, J., dissenting) (quoting A. Heribers, Uncomanon LAw 192 (1936)). The reference is to a fictional opinion conceived by A. P. Herbert.

$79274 \mathrm{Md}$. at 185, $333 \mathrm{A.2d}$ at 315 .

so Id. at 186, 333 A.2d at 316 (quoting U.C.C. $\$ 2-316$, Comment I) (emphasis supplied by court). 
The majority concluded that the purpose of protecting the buyer from surprise required that "as is" disclaimers also be conspicuous.

In advancing this purposive interpretation the majority did not derive as much from the language of the statute as they might have. For example, they did not note that section 2-316(3)(a) expressly applies "unless the circumstances indicate otherwise," or that "as is" and "with all faults" disclaimers are merely illustrative examples of "other language which in common understanding calls the buyer's attention to the exclusion of warranties and makes plain that there is no implied warranty." 81 Although they did bolster their opinion with Comments 6 and 7 to section 2-316, ${ }^{82}$ the majority did not turn to the third step of purposive interpretation and consider the historical context. In particular, they did not try to define those settings in which disclaimers such as "as is" or "with all faults" had customarily been employed. Had they done so, they would have discovered that these "magic words" were drawn from bills of sale in specialized kinds of transactions such as foreclosure sales, the sale of seconds or rejects, and the sale of second hand goods or goods long in storage. ${ }^{83}$ In these special cases, common commercial understanding may preclude implied warranties. A precise purposive interpretation of these disclaimer provisions need not conclude that all "as is" disclaimers must be conspicuous, but would require that they either be conspicuous or be used in circumstances in which commercial understanding negates the presence of implied warranties of quality. Read in this fashion the warranty disclaimer provision assumes a coherence not detectable from mere reference to Webster's Dictionary. These provisions are not being touted as models of draftsmanship; quite the contrary will be maintained in

s1 U.C.C. $\$ 2-316(3)(a)$.

82 Comment 6 states that $\$ 2-316(3)$ is addressed to "common factual situations in which the circumstances surrounding the transaction are in themselves sufficient to call the buyer's attention to the fact that no implied warranties are made or that a certain implied warranty is being excluded." Comment 7 indicates that $\$ 2-316$ (3) (a) is "merely a particularization of paragraph (c) which provides for exclusion or modification of implied warranties by usage of trade." See 274 Md. at 186-88, 333 A.2d at 316-17.

834 R. Henson \& W. Davenport, Unfoorm Laws Annotated 105 (master ed. 1968). Judicial disregard of this historic context is not uncommon. See DeKalb Agresearch, Inc. v. Abbott, 391 F. Supp. 152 (N.D. Ala. 1974) (alternative holding), affd, 511 F.2d 1162 (5th Cir. 1975); Gilliam v. Indiana Nat'l Bank, - Ala. App. -, 337 So. 2d 352 (1976). Ironically, the Abbott opinion cites Henson and Davenport for the proposition that an "as is" disclaimer form need not be conspicuous, without noting that Henson and Davenport contemplated the use of such forms only in the special contexts where the absence of the warranty is understood. 391 F. Supp. at 155. The opinion exemplifies the non-purposive technique of summary reliance on authority examined at text accompanying notes 120-33 infra. 
Part III. ${ }^{84}$ Nevertheless, if one considers all of the statutory language, the Comments, and the historic context, what at first seems contradictory may be explained. A purposive interpreter seeks a vision of purpose equal to the complexity of the draftsmen's undertaking. Thus, the fourth and final step of purposive construction is: After considering statutory language, Official Comments and historic context, in seriatim, examine these factors in combination for a coherent interpretation.

\section{B. Retreat to the Pre-Code Standard}

Another way in which courts have avoided purposive interpretation of the U.C.C. is to translate Code language into a pre-Code legal standard. A clear example of this methodology is the ill-fated opinion of the Rhode Island Supreme Court in American Card Co. v. H.M.H. Co. ${ }^{85}$ in which an allegedly secured creditor attempted to establish its priority in an equity receivership proceeding. The creditor had filed a standard-form financing statement signed by the debtor that described certain tools and dies of the debtor as collateral. However, a separate written security agreement had not been executed. The creditor's agent testified (apparently without contradiction) that the treasurer of the debtor had agreed to the designation of the tools and dies as collateral security. Thus, the court faced the issue whether a standard-form financing statement could operate as a security agreement where there was only parol evidence that the parties intended the statement to have that effect.

The creditor invited the court to interpret purposively. Pointing to the statutory definition of a security agreement ("an agreement which creates or provides for a security interest") in section $9-105(1)(l)$, the creditor argued that the drafters intended the question whether a security interest had been created to be a question of fact dependent on the parties' words and conduct in the particular circumstances. ${ }^{86}$ On its facts American Card presented a difficult case for purposive interpretation because a financing statement may be filed before the parties have agreed on the terms of the security arrangement. ${ }^{87}$ The Rhode Island court, however, did not even make the effort, finding section 9-105(I) $(l)$ to be "not decisive of the

84 See text accompanying notes 157-61 infra.

8597 R.T. 59, 196 A.2d 150 (1963).

$86 \mathrm{Id}$. at $61,196 \mathrm{~A} .2 \mathrm{~d}$ at 151-52.

87 U.C.C. $\$ 9-402(1)$. The issue is examined from a purposive viewpoint at text accompanying notes 210-21 infra. 
special problem posed in the instant case." 88 Instead, it looked to the language of section 9-203(1)(a) which declares nonpossessory security interests to be unenforceable unless "the debtor has signed a security agreement which contains a description of the collateral." The court then concluded: "The financing statement which the claimants filed clearly fails to qualify also as a security agreement because nowhere in the form is there any evidence of an agreement by the debtor to grant claimants a security interest." 80

Rather than resolve the issue in terms of the Code's own definition of a security agreement, the court provided its own: a security agreement must contain a granting clause. In making this translation, the court lapsed into pre-Code vernacular. The granting clause is, of course, standard in real estate conveyances and pre-Code security devices patterned after them, such as the chattel mortgage. The principal objective of article 9 , however, was to simplify the old law of chattel mortgages and other independent security devices. $^{90}$ Interpreting the Code in terms of the pre-Code norm was bound to do violence to this objective.

The effect of such interpretations is illustrated by decisions like In re Shelton ${ }^{01}$ in which the Eighth Gircuit Court of Appeals refused to enforce a security arrangement covering an automobile, even though the debtor had signed an application for a certificate of title that indicated the existence of the security interest, or Evans $v$. Everett ${ }^{92}$ in which a financing statement was initially held insufficient even though it recited that the collateral secured a note for money advanced to produce crops. In these cases, there was written evidence of existing security interests, but no affirmative language of conveyance of the type contemplated by the American Card court.

These decisions, predicated on the use of the pre-Code standard, frustrated the statutory policy of simplifying formalities and effectuating the actual intent of the parties. ${ }^{93}$ They introduced what the First Gircuit Court of Appeals has described as a "continuing tension in all cases in this area" between the perceived need to effectuate that intention and the policy of uniform interpretation of

8897 R.I. at 61,196 A.2d at 152.

s9 Id. at 63, $196 \mathrm{~A} .2 \mathrm{~d}$ at 152 (emphasis supplied).

90 U.C.C. \$9-101, Comment; Gilmore, Security Law, Formalism \& Article 9, 47 NeB. L. Rev. 659, 668 (1968).

91472 F.2d 1118 (8th Cir. 1973).

9210 N.C. App. 435, 179 S.E.2d 120, rev'd, 279 N.C. 352, 183 S.E.2d 109 (1971).

93 See Weinberg, Toward Maximum Facilitation of Intent to Create Enforceable Article Nine Security Interests, 18 B.C. Indos. \& CoM. L. REv. 1 (1976). 
the Code.94 In fact, courts that construed only the language defining a security agreement in section 9-105 (or supplemented that language with their dictionaries) came closer to the results intended by the drafters. At least they perceived that a writing could "provide for" a security interest without containing affirmative and formal present language of conveyance. ${ }^{95}$

To be sure, at least two policies are manifested in the statement of the "formal requisites" of a security arrangement in article 9. In addition to the desire to simplify, there is a countervailing evidentiary policy. The drafters designed section $9-203$ as a Statute of Frauds that would require a written agreement as a condition of enforceability even against the debtor ${ }^{96}$ and would minimize "the possibility of future dispute as to the terms of the security agreement and as to what property stands as collateral for the obligation secured." 97 Clearly the language of the Code itself and the commentary-not a pre-Code formula-is the best guide to the intended resolution of these conflicting policies.

A preliminary examination of judicial failures to interpret purposively section 9-203 reveals that the first step of the methodology proposed here should be modified in order to focus the interpreter's attention on the language of the Code instead of past formulas, and on the possibility that a multiplicity of purposes motivated the drafters' language. With the added terminology emphasized, that step now reads: Start with the statutory language and read it all as it stands with an eye to the underlying purpose or purposes and the relationship between them.

The purposive interpreter will encounter instances in which the statutory language evidences a modification of pre-Code legal standards, but the drafters' precise purposes are not apparent from their choice or arrangement of the statutory words, nor do the Comments and drafting history explain why the new language was selected. $\mathrm{He}$ is approaching a "Hard Code Case," ${ }^{88}$ and must retreat, as indicated above, ${ }^{99}$ to the perceived impact on the central, albeit general, Code objectives stated in section 1-102(2). The purposive interpreter cannot assume that every change in wording from the pre-Code law was intended to produce substantive changes.

94 In re Numeric Corp., 485 F.2d 1328, 1331 (1st Cir. 1973).

95 E.g., In re Amex-Protein Dev. Corp., 504 F.2d 1056 (9th Cir. 1974).

96 U.C.C. $\$ 9-203$, Comment 5.

97 Id., Comment 3.

98 See text accompanying notes 216-21 infra.

99 See text accompanying notes 20-21 supra. 
Consider, for example, the duty of a buyer who has accepted goods to give notice of breach under section 2-607 "within a reasonable time after he discovers or should have discovered any breach . . . or be barred from any remedy . . . ." 100 This "notice of breach" requirement was worded somewhat differently in the Uniform Sales Act. The analogous section read:

Acceptance does not bar action for damages. - In the absence of express or implied agreement of the parties, acceptance of the goods by the buyer shall not discharge the seller from liability in damages or other legal remedy for breach of any promise or warranty in the contract to sell or the sale. But, if, after acceptance of the goods, the buyer fails to give notice to the seller of the breach of any promise or warranty within a reasonable time after the buyer knows, or ought to know of such breach, the seller shall not be liable therefor. ${ }^{101}$

The differences in the emphasized statutory language could be construed to make a difference in cases involving late delivery of goods. In such cases the buyer "knows" of late delivery without examining the goods; he does not "discover" the breach by examining the goods after delivery, as he would in a more typical breach of warranty dispute. Thus, a court might interpret the word "discover" as an implication that cases of late delivery are totally exempt from the notice of breach requirement.

In Jay V. Zimmerman Co. v. General Mills, Inc., ${ }^{102}$ a federal district court reached this very conclusion, although it was apparently unaware of the contrast between the language of section 2-607 and that of the Sales Act. Attempting the first step of purposive interpretation, the court concluded that the purpose of the notice "is to inform the seller of matters which would not normally come to the buyer's attention until after the goods came into his possession." 103 If the court had turned to the third step of purposive interpretation, and compared the language of section 2-607 with its historical antecedents, it could have buttressed its conclusion by noting the change in language.

Thorough historical analysis, moreover, would have gone beyond noting the new statutory language. In studying case law history, the Zimmerman court would also have learned that decisions

100 U.C.C. $\$ 2-607$ (3) (a) (emphasis supplied).

101 UNAFORM SALES ACT $\$ 49$ (emphasis supplied).

102327 F. Supp. 1198 (E.D. Mo. 1971).

103 Id. 1204 (emphasis in original). 
under the Sales Act had applied the notice requirement to late deliveries on the ground that it was designed not merely to inform the seller of nonconformities, but also to place the seller on notice that the buyer regarded his conduct as a breach of contract that he was not willing to waive or disregard.104 When the seller acquired this information, he would realize that he had to scrutinize the facts of the transaction, and he must cure, settle, or resist depending upon his assessment of them. Moreover, if the Zimmerman court, following the second step of purposive interpretation, had looked to the Comments to section 2-607, it would have discovered that the Sales Act's broader rationale had survived the transition to the U.C.C. intact: "The notification which saves the buyer's rights under this Article need only be such as informs the seller that the transaction is claimed to involve a breach, and thus opens the way for normal settlement through negotiation." 105 Once the settlement function of notice of breach is recognized, notice should be required in cases of late delivery as well as in breach of warranty disputes. ${ }^{108}$

The section 2-607 example illustrates that not every instance of changed language in the Code manifests a desire to produce substantive change. By noting the silence of the Comments on the change in language and their approval of the settlement function, which was the basis of pre-Code case law, the purposive interpreter is able to conclude that the change of wording was not directed at the late delivery problem.

Two objections could be raised at this point to the course of purposive interpretation as outlined. First, it might be urged that purposive interpretation, as illustrated by the analysis of the late delivery problem, improperly makes the Comments-the statement of purposes-more authoritative than the statutory text..107 Second, it could be argued that the Code frequently incorporates, rather than alters, common law terminology; in such cases the provision should be construed in light of pre-Code decisions. Both of these objections may be evaluated with respect to the litigation centering on section 9-305 of the Code, which exemplifies the continued use of pre-Code language.

1045 S. Whutston, Contracts $\$ 714$, at 409 (3d ed. 1961). See American MIfg. Co. v. United States Shipping Bd. Emergency Fleet Corp., 7 F.2d 565 (2d Cir. 1925); In te Gotham Silver Co., 91 F. Supp. 520 (D.N.J. 1950).

105 U.C.C. $\$ 2-607$, Comment 4.

100 This was the reasoning of the Fifth Circuit Court of Appeals in Eastern Airlines, Inc. v. McDonnell Douglas Corp., 532 F.2d 957, 970-73 (5th Cir. 1976), in refusing to follow the Zimmerman decision. The court did not even discuss the difference in statutory language between the Sales Act and the Code.

107 See note 52 supra \& accompanying text. 
Section 9-305 allows security interests in most forms of collateral to be perfected by pledging, that is, by the secured party taking possession of the collateral. The section reads:

A security interest in letters of credit and advices of credit . . . goods, instruments, negotiable documents or chattel paper may be perfected by the secured party's taking possession of the collateral. If such collateral other than goods covered by a negotiable document is held by a bailee, the secured party is deemed to have possession from the time the bailee receives notification of the secured party's interest. A security interest is perfected by possession from the time possession is taken without relation back and continues only so long as possession is retained, unless otherwise specified in this Article. The security interest may be otherwise perfected as provided in this Article before or after the period of possession by the secured party.

The term "possession" is not defined by the Code, but its use clearly refers to the common law concept. The Comments to section 9-305 begin by declaring: "As under the common law of pledge, no filing is required by this Article to perfect a security interest where the secured party has possession of the collateral." "Possession," however, is not a word with direct ties to concrete experience; it is an abstract concept that courts have translated in different ways even within the law of pledges. At times courts have equated possession in pledge cases with "absolute dominion and control over the property." 108 On other occasions, including those involving bulky goods, they have deemed that something less-"constructive possession"would suffice. ${ }^{109}$ How much of this case-law baggage does the term "possession" carry with it into the Code?

This question was the dispositive issue in In re Copeland.110 Copeland had guaranteed a loan to one of his enterprises, and he entered into a pledge agreement covering certain stock to secure his guaranty. The stock certificates, however, were not delivered to the creditor. Instead, they were placed in the hands of the Wilmington Trust Company under an escrow agreement directing that they be

108 In re Dolly Madison Indus., 351 F. Supp. 1038 (E.D. Pa. 1972), affd mem., 480 F.2d 917 (3d Cir. 1973); Qualley v. Snoqualmie Valley Bank, 136 Wash. 42, 238 P. 915 (1925).

109 See 1 G. Gumore, Securtry Interests in Personal Property $\$ 14.2$ at $440 \&$ n.2 (1965). 1975).

110531 F.2d 1195 (3d Cir. 1976), affg in part 391 F. Supp. 134 (D. Del. 
held for safekeeping subject to the pledge agreement. The agreement specified that the shares were to be delivered to the creditor fifteen days after its written demand upon a default of fifteen days duration in the payment of the loan itself.

Both the common law and the Code contemplate the possibility of a secured party taking possession of collateral through an agent. One example of such an agency relationship appears on the face of section 9-305: "If such collateral other than goods covered by a negotiable document is held by a bailee, the secured party is deemed to have possession from the time the bailee receives notification of the secured party's interest." Nevertheless, the federal district court in Copeland, after a frank and painstaking review of the authorities, concluded that the common law required a secured party claiming possession through his agent or bailee to exercise an "absolute dominion and control" over the property. 111 It further found that such control could not be achieved by escrow because the escrow agent's duty is to follow the escrow agreement rather than the instructions of the secured party. ${ }^{112}$ For example, the creditor in Copeland could not have unilaterally terminated the escrow agreement and obtained possession of the securities prior to default as would have been possible if the certificates had been left with its attorney for safekeeping.

Having eliminated Wilmington Trust as a bailee with notice under the common law, the district court then faced the question whether the common law doctrine controlled its interpretation of section 9-305. It concluded that it did not. The court's reasoning, later upheld by the Third Circuit, reflects use of the methods of purposive interpretation. The function of the possession requirement is to alert third parties that the pledged assets are encumbered. This purpose is not expressly stated in the text of the Code or the Comments, but it is central to the pledge idea as set forth in common law pledge decisions. ${ }^{113}$ Retention of the pledge as a means of perfection under the Code manifests a continuation of this policy. The district court concluded that the escrow arrangement, by placing the stock in the hands of Wilmington Trust, adequately served this notice function. ${ }^{114}$ As the Third Circuit later explained:

It does not follow . . . that possession of the collateral must be by an individual under the sole dominion and 
control of the secured party . . . Rather, we believe that possession by a third party bailee, who is not controlled by the debtor, which adequately informs potential lenders of the possible existence of a perfected security interest satisfies the notice function underlying the "bailee with notice" provision of $§ 9-305 .{ }^{115}$

This example shows how the Code may utilize common law terminology without incorporating common law doctrine. By identifying the purpose of section 9-305-to alert third parties to the existence of perfected security interests-the court in Copeland properly rejected common law possession doctrine on the facts of the case before it, because in that context the doctrine was inconsistent with its purpose.

The Copeland approach also refutes the notion that purposive interpretation exalts the Code commentary over the text. Either court in Copeland might have drawn upon commentary that suggests a contrary result to the decision that was-quite properlyreached. This commentary is appended to section 9-205, which repeals the "policing" rule of Benedict $v$. Ratner. .116 $^{11}$ That decision required policing of collateral and its proceeds in the areas of receivables and inventory financing even if a public filing had been made. After rejecting the Benedict rule, section 9-205 concludes: "This section does not relax the requirements of possession where perfection of a security interest depends upon possession of the collateral by the secured party or by a bailee." The commentary to section 9-205 carries this statement a step further. It states:

The last sentence is added to make clear that the section does not mean that the holder of an unfiled security interest, whose perfection depends on possession of the collateral by the secured party or by a bailee (such as a field warehouseman), can allow the debtor access to and control over the goods without thereby losing his perfected interest. The common law rules on the degree and extent of possession which are necessary to perfect a pledge interest or to constitute a valid field warehouse are not relaxed by this or any other section of this Article. ${ }^{117}$

The concluding sentence of this Comment appears directly contrary to the reasoning of the Copeland courts. There are reasons, 
however, to reject its applicability to the escrow agent context. First, the concluding sentence goes beyond the policy stated in the text of section 9-205 that nothing in "this section" relaxes the common law rules. Second, as the first sentence of the Comment indicates, the common law result anticipated by the drafters was to assure that the debtor did not maintain access to or control over the collateral. The decision in Copeland is consistent with this policy. Third, the Comment is addressed to a different problem than that faced in Copeland. The concluding sentence of section 9-205 and Comment 6 were added to the Code after field warehouse interests urged the drafters to exempt them from the filing requirement on the ground that the field warehouse is an extended pledge. ${ }^{118}$ The drafters wished to ensure in section 9-205 that the field warehouse was a real, as well as an extended, pledge. Their attention was not focused on escrow arrangements. Because purposive interpretation subjects the commentary as well as the text to contextual analysis, Comment 6 to section 9-205 is not contrary to the result reached in Copeland, and there need be little fear that purposive interpretation will lead to the denigration of the authority of the Code's text in favor of the commentary.

Through its decision, the Copeland court was able to encourage the use of the escrow arrangement, an important contemporary commercial device. Such purposive interpretation thus maximizes statutory flexibility, consistent with one of the Code's central underlying objectives.119 The example also demonstrates that the Comments, as such, do not enjoy a priority status in the process of purposive interpretation. In Copeland, the controlling policy was articulated in the common law history, and that source of data shaped the analysis.

\section{Retreat to Authority}

A third way in which courts avoid reading the Code in light of its purposes is by interpreting the Code to mean what authorities say it means. This tendency is not new to commercial law or to statutory interpretation generally. Professor Gilmore has described similar experiences under earlier uniform acts:

118 U.C.C. $\$ 9-205$ \& Comment ( 1956 Recommendation at 269-70).

119 U.C.C. $\$ 1-102(2)(a) \&(b)$. For a contrasting non-purposive reading of \$ 9-305 that would blunt the adaptive capacity of the Code, see In re Dolly Madison Indus., Inc., 351 F. Supp. 1038 (E.D. Pa. 1972), aff'd mem., 480 F.2d 917 (3d Cir. 1973). See also Stein v. Rand Constr. Co., 400 F. Supp. 944 (S.D.N.Y. 1975). But see In re Bialk, 16 UCC Rep. 519 (W.D. Mich. 1974); Estate of Hinds, 10 Cal. App. 3d 1021, 89 Cal. Rptr. 341 (1970) (supporting the result in Copeland). 
The general understanding of the profession seems to have been that the codifying statutes were merely declaratory of the common law-like the Restatements of the following generation. Since lawyers knew what the common law was, there was no particular reason for them to pay much attention to the statutory text or to take the statute seriously or even to take it as a statute. In the case of the Sales Act, this tendency was reinforced by the fact that the draftsman, Professor Williston, promptly produced a magisterial treatise on sales to accompany the statute. In the Sales Act case law nothing is more common than copious allusions to and quotations from Williston on Sales; nothing is rarer than a direct reference to the Sales Act itself; judicial analysis of the statutory text was almost nonexistent. ${ }^{120}$

The U.C.C. is not so declaratory of the common law as was the Sales Act, and we do not have a Willistonian exegesis of it to date. Nevertheless, courts have not been above retreat to authority on occasion. One example is Scholl $v$. Tallman, ${ }^{121}$ in which the dispute centered on the common practice of using a check marked "payment in full" as a means of trying to effect an accord and satisfaction. Under the common law doctrine of most states, a party receiving and cashing such a check with respect to a disputed debt was bound to an accord and satisfaction even though he marked through the words "payment in full" or wrote "under protest." His act of collecting the check was said to speak louder than any verbal reservation of rights. ${ }^{122}$ The rationale of this doctrine is that under the bank collection process such instruments will normally be paid without the drawer of the check being afforded the opportunity either to consent to the deletion of his condition or to withdraw his check.

The question addressed by the court in Scholl was whether this doctrine had been changed by section 1-207 of the Code. That provision reads:

A party who with explicit reservation of rights performs or promises performance or assents to performance in a manner demanded or offered by the other party does not thereby prejudice the right reserved. Such words as "without prejudice", "under protest" or the like are sufficient.

120 Gilmore, On Statutory Obsolescence, 39 U. CoLo. L. REv. 461, 466-67 (1967) (footnote omitted).

121 - S.D. $\rightarrow 247$ N.W.2d 490 (1976).

1226 A. Corbin, Conbin on Contracts $\$ 1279$ at 130 (2d ed. 1962). 
This is a formula of considerable generality, as attested to by its placement in the introductory article of the Code. Nonetheless, the South Dakota Supreme Court in Scholl did not attempt to define the policy section 1-207 seeks to effectuate by reference to the language of the section or its Comments or history. It stated instead: "The effect of this section on the doctrine of accord and satisfaction as it developed at common law has never been addressed by a court of last resort. We therefore look to other sources for guidance in this case of first impression." ${ }^{123}$ The sources to which the court turned were:

1) Dictum in a New York county court decision stating that it would have applied section 1-207 to a reservation of rights on a payment in full check if it had not already concluded that there was no accord and satisfaction on the facts of the case because there was no dispute about the amount owed. ${ }^{124}$ A dispute was a necessary precondition to finding consideration for the common law accord and satisfaction.

2) Language in a North Carolina Court of Appeals decision (characterized as dictum in $S$ choll) that did not involve a payment in full check but a check tendered under a settlement agreement that arrived after the time required by that agreement. The North Carolina court said that a reservation of rights on the check prevented it from operating as a full payment. ${ }^{125}$

3) A report prepared by Professors Hogan and Penney for the New York Commission on Uniform State Laws that assumed, without explanation, that section 1-207 operated in the context of a reservation of rights on a payment in full check. ${ }^{126}$

4) A more extensive discussion relying on the previously listed authorities in Professors Summers' and White's Uniform Commercial Code. ${ }^{127}$

123 _ S.D. at _, 247 N.W.2d at 492.

124 Hanna v. Perkins, 2 UCC REP. 1044 (Westchester County Ct., N.Y. 1965). 125 Baillie Lumber Co. v. Kincaid Carolina Corp., 4 N.C. App. 342, 167 S.E.2d 85 ( 1969 ).

126 Commission on UNIFORM State Laws, New York AnNotations to UNIFORM Commercial Code and RePORT OF Commission ON UNIFORM STATE Laws to Legislature of New YoRk State 19-20 (1961).

127 J. White \& R. Summers, UntForm Commerclal Code $\$ 13-21$ (1972). White and Summers take as their point of departure the view that a check for less than the contract amount but offered in full settlement "inflicts an exquisite form of commercial torture on the payee." Id. One observer suggests "overreaching debtors" such as insurance companies or employers will offer an inadequate check in order to effect an unconscionable settlement. See Note, Role of the Check in Accord and Satisfaction: Weapon of the Overreaching Debtor, 97 U. PA. L. REv. 99 (1948). 
The authorities listed were "persuasive" to the South Dakota court, but those authorities, like the decision itself, eschewed purposive analysis of the provision. They did not start with an effort to see how the language of section 1-207 correlates with the payment in full situation. Such an effort would have shown that the correlation is weak. Section 1-207 refers to a party who "performs or promises performance," or who "assents to performance in a manner demanded or offered by the other party." A party collecting a check under reservation of rights does not "perform or promise performance." By rejecting the check as "payment in full," such a party specifically rejects the manner in which the check was offered.

Moreover, utilization of the second step of purposive interpretation would reveal that the commentary strongly suggests that section 1-207 was not aimed at an accord and satisfaction. Comment 1 speaks of providing "machinery for the continuation of performance along the lines contemplated by the contract despite a pending dispute," while Comment 2 speaks of "interim adjustment in the course of performance." An accord and satisfaction extinguishes a dispute; it does not put it on ice.

Finally, turning to the third step of purposive interpretation, the drafting history of section 1-207 provides interesting, if inconclusive, insights. The provision began its Code existence in article 2, the sales article. Llewellyn included the provision in the Revised Sales Act where it was intended as part of a series of sections aimed "at smoothing the course of performance." 128 In the early drafts of the Code it coexisted with a provision in article 3 which expressly addressed the problem of the payment in full check, allowing it to operate unless "unconscionable advantage" was taken by the obligor. This provision extended the common law doctrine of accord and satisfaction by allowing the payment in full instrument, if collected, to extinguish claims even in the absence of a dispute. In the Spring, 1950 Draft, section 1-207 was transferred to the introductory article, but article 3 approval of the payment in full instrument remained. ${ }^{129}$ Not until the 1954 Recommendations was the article 3 provision removed, not because of inconsistency with section 1-207, but "on the ground that it would work hardship, and was open to abuse." 130

Neither the language, nor commentary, nor history of section 1-207 is independently conclusive. Read together, however, they

128 ALI Unform Revised SAIES Act, Intro. Comment to Part IV-Performance, $\$ 71-90$, at 237 (Proposed Final Draft No. 1, 1944).

129 U.C.C. $\$ \$ 1-207,3-802$ (1950 version).

130 U.C.C. $\$ 3-802$ \& Reason for Change 25 (1954 amendments). 
strongly suggest that the provision was designed to deal with problems of waiver, election of remedies, and estoppel rather than with attempted accord and satisfaction. ${ }^{131}$ If the seller in tendering goods insists, despite a contrary view by the buyer, that, "This is what the contract provides for," can the buyer accept what he regards as a significant but non-conforming tender without slipping into a waiver the pre-Code sales law was so ready to invoke? Can a seller take a payment after the buyer announces, "This is what I owe you and I will pay no more," without waiving his claim to a larger amount? Similar waiver problems arise under other articles of the Code. ${ }^{132}$ They do not involve attempts at express compromise but allegations of waiver based on conduct.

The South Dakota court did not pursue the probable policy of section 1-207 because it was already committed to the view that a "payment in full" instrument is undesirable. Indeed, the pre-Code law in South Dakota rejected the normal common law doctrine on preservation of rights in this context for the same reason..$^{133}$

This Part has described three methodologies used by courts to avoid purposive interpretation. It has shown that those methodologies are not tethered by the legislative will. To understand how the technique described here as "purposive interpretation" operates to reflect that will, we must analyze the directive steps outlined above, and consider the mechanics of the interpretation process.

131 The provision has been the focus of government contract litigation involving waiver-election-estoppel problems. Cities Serv. Helex Inc. v. United States, $\mathbf{5 4 3}$ F.2d 1306 (Ct. Cl. 1976); Northern Helex Co. v. United States, 455 F.2d 546 (Ct. Cl. 1972). Because the Bailee Lumber case cited by the Scholl court did not involve tender of a payment in full check, but non-conforming tender of a settlement check, it also appears to be concerned with the waiver problem. Support for this interpretation of $\$ 1-207$ can be found in Hawkland, The Effect of U.C.C. $\$ 1-207$ on the Doctrine of Accord and Satisfaction by Conditional Check, 74 CoM. L.J. 329 (1969); Comment, Accord and Satisfaction: Conditional Tender of Check Under the Uniform Commercial Code, 18 Bufralo L. Rev. 539 (1969).

132 For example, a debtor who receives a notification of disposition of collateral which he believes does not conform to U.C.C. \$9-504 may nevertheless seek to maximize the amount received in the disposition, without waiving his right to object to the sufficiency of the notice. Similarly, a drawee who believes an instrument presented for payment is late under $\$ 3-506$ may nevertheless wish to examine the instrument and seek to determine if it is otherwise properly payable, without waiving his right to object to the timeliness of the presentation.

133 - S.D. at —, 247 N.W.2d at 491-92.

The Scholl court's discussion of $\$$ I-207 was actually superfluous to its result. It could have merely stated the pre-Code South Dakota rule, and then held that nothing in the Code displaced that doctrine. Its discussion of $\$ 1-207$ was, in effect, an attempt to preserve South Dakota's peculiar pre-Code doctrine. 


\section{An Analysis of Purposive Interpretation}

\section{A. Objections to Purposive Interpretation}

The extent to which courts ignore legislative purpose in Code cases reflects a basic skepticism about the utility of using formulations of purpose to guide decisionmakers. To be sure, there are certain traditional objections to purposive interpretation of any type of legislation. For example, it has been urged that legislative purpose is essentially unknowable because the legislature is a collective, the voice of not one but many persons, with varying motives. As Professor Radin stated long ago: "A legislature certainly has no intention whatever in connection with words which some two or three men drafted, which a considerable number rejected, and regard to which many of the approving majority might have had, and often demonstrably did have, different ideas and beliefs." 134

Radin's argument confuses legislative purpose with an individual legislator's motives. The purposive interpreter is not interested in the secret motives that lead one or more legislators to vote affirmatively; his inquiry concerns only objectively manifested goals. This view is consistent with the attitudes of Justices Holmes and Frankfurter, who objected to talk of legislative "intent." 135 Indeed, confusion on this point may explain some of the appeal of the "plain meaning" approach to legislative interpretation. One may concede that a secret, idiosyncratic meaning attached to legislative words by even a chief draftsman is not relevant to the force of a legislative act, however, without concluding that only one ordinary meaning can be attributed to statutory language.

Another traditional objection to purposive inquiry is that indications of purpose not expressed in the statute itself are likely to be reflective not of the legislative will but of partisan views that could not achieve majority approval. Much of the maneuvering in Congress to make "legislative history" may be subject to criticism along these lines. ${ }^{136}$ This criticism loses most of its force with respect to U.C.C. litigation, however, because of the programmatic way in which those responsible for the Code project sought to manifest their objectives in the text and its accompanying commentary. ${ }^{137}$

134 Radin, Statutory Interpretation, 43 HARv. L. REv. 863, 870 (1930).

135 See Frankfurter, Some Reflections on the Reading of Statutes, 47 Conon. L. Rev. 527, 538 (1947); Holmes, The Theory of Legal Interpretation, 12 Harv.

L. REv. 417 (1899).

136 See Curtis, A Better Theory of Legal Interpretation, 3 VAND. L. Rev. 407, 411-12 (1950); Murphy, supra note 43, at 1316.

137 See notes $19-27$ \& accompanying text supra; note 52 supra. 
Of greater concern to the purposive interpreter of the Code are certain contemporary objections to his technique. One of these objections is that the legislators' inability to predict the future produces an "indeterminacy of aim." 138 Professor Hart illustrates this argument with reference to his ordinance barring vehicles from a public park. ${ }^{139}$ If the purpose of this law is to maintain peace and quiet, we know that the legislature desired to exclude cars, buses, and motorcycles:

We have initially settled the question that peace and quiet in the park is to be maintained at the cost, at any rate, of the exclusion of these things. On the other hand, until we have put the general aim of peace in the park into conjunction with those cases which we did not, or perhaps could not, initially envisage (perhaps a toy motor-car electrically propelled) our aim is, in this direction, indeterminate. We have not settled, because we have not anticipated, the question which will be raised by the unenvisaged case when it occurs: whether some degree of peace in the park is to be sacrificed to, or defended against, those children whose pleasure or interest it is to use these things. ${ }^{140}$

Apart from the legislature's inability to foresee the types of disputes that will arise, one might contend that statements of purpose, like the statutory text itself, suffer from the infirmities common to all language. As expressed by Professor Twining: "Statements of purpose are at least as susceptible as are statements of 'substantive' rules to vagueness, ambiguity, obscurity, difficulty of reconciliation with other statements, and so on." 141 In order to evaluate the objections based on the indeterminacy of aim and the infirmities of language, certain basic features of language itself must be considered.

\section{B. Viewpoints of Linguistic Philosophy}

"Philosophy is a battle against the bewitchment of our intelligence by means of language," wrote Wittgenstein,, ${ }^{142}$ reflecting the preoccupation of modern philosophy with linguistic problems. Certain viewpoints derived from this preoccupation serve to illustrate how purposive interpretation may assist the decisionmaker, notwith-

$138 \mathrm{H}$. HART, supra note $\mathrm{I}$, at 125.

139 See text accompanying notes 3-7 supra.

$140 \mathrm{H}$. HART, supra note 1 , at 126 .

141 W. TwinING, supra note 23 , at 324 .

142 L. Wittgenstenn, Philosophucar Investigations 47e (1963). 
standing the objections lodged above. These viewpoints include the following:

1) Interpretation (or explanation) of language is a process of translation. An expression which is not clear in a given context can be translated into a new formula, the impact of which on a given dispute is more easily demonstrable. Such translation is necessary because of certain characteristics of natural languages, including their tendency toward ambiguity. Ambiguity exists because a word or other expression may have more than one meaning. Ambiguity, however, is not an absolute; its presence and degree are relative to a certain context and a given interpreter. According to Professor Black, "a word (or other sign) is ambiguous in a certain usage when in that occurrence the interpreter (or hearer) is unable to choose between alternative meanings of the word, any of which would seem to fit the context." ${ }^{143}$ Wittgenstein has illustrated the effect of translation on ambiguity by imagining a primitive word game played by a builder and his assistant. When the builder requires a unit of construction material, he calls out to his assistant the command "Slab!" The assistant has been trained to respond to this call by fetching the slab. In some building situations with untrained assistants, however, the builder would have to translate the command "Slab!" into "Bring me a slab!" This may be necessary because our language contains the possibility of other meanings of the simple command "Slab!," such as "Hand me a slab!" or "Bring him a slab!" 144

Translation may also be appropriate when language is vague. Vagueness differs from ambiguity in that a vague expression is subject not to multiple meanings, but rather to uncertainty whether a given state of affairs is to be embraced within that expression. To illustrate the nature of vagueness Black utilized the term "chair," defined as "a separate seat for one."

One can imagine an exhibition in some unlikely museum of applied logic of a serious of "chairs" differing in quality by least noticeable amounts. At one end of a long line, containing perhaps thousands of exhibits, might be a Chippendale chair: at the other, a small nondescript lump of wood. Any "normal" observer inspecting the series finds extreme difficulty in "drawing the line" between chair and not-chair. . . .

143 M. Black, Critical Thunking 185 (2d ed. 1952).

$144 \mathrm{~L}$. Wrtigenstein, supra note 142 , at $9 \mathrm{e}$. 
$[A]$ the extremities of the series little or no uncertainty is felt, but the observer grows increasingly doubtful when the borderline cases in the center are approached: "everybody" agrees that the Chippendale chair is a chair, "nobody" wants to sit upon, still less to call a chair, a shapeless lump of wood, but in intermediate cases personal uncertainty is a reflection of objective lack of agreement. ${ }^{145}$

Vagueness is considered to be present, in varying degrees, in all natural language, ${ }^{146}$ and many problems of statutory interpretation stem from vague legislation. From the point of view of the draftsman, however, vagueness is not always a vice. One way to hedge against his inability to predict future occurrences is to choose terminology with a wide range of indeterminacy. Use of this drafting technique will invite the judiciary to contract or expand a statutory classification in light of subsequent developments.

2) The meaning of a message can be best translated by first viewing the message as a whole, rather than starting with its constituent units. Vagaries of reference such as ambiguity tend to be dispelled by consideration of the entire message. In fact, when language is used to make an assertion or command, the meaning of the words is a function of their use. As explained by Ryle: "Wordmeanings do not stand to sentence-meanings as atoms to molecules or as letters of the alphabet to the spellings of words, but more nearly as the tennis-racket stands to the strokes which are or may be made with it." ${ }^{147}$

3) Expressions vary in the degree to which they are abstractions of sense experience; it is normally easier to apply a less abstract formula to a given fact situation. This viewpoint mirrors a common sense attitude, which linguistic philosophy attempts to explain. The first level of language acquisition-upon which all else is ultimately built-consists of descriptions of events in the concrete world of material objects. Communication at this level is exemplified by the occasion sentence. A child seeing a certain animal behaving in a certain manner, in a certain place, says, "A rabbit is hopping across the lawn." The truth of this statement can be determined by observation of the experiential framework in which it was made, a situa-

145 M. Brack, Language \& Phroosophy 32-33 (1949) (footnotes omitted).

146 Id. 26-28. Both "ambiguity" and "vagueness" should be distinguished, at least at the conceptual level, from "generality." The generality of an expression refers to the multiplicity of objects to which it applies. Id. 31.

147 Ryle, The Theory of Meaning, in Readnas in Semantics 219, 229 (1974). 
tion which can be observed simultaneously by both the child and his parent. At this level of discourse, reinforcement of conventionally correct language behavior, or correction of "mistakes," can be crisp and clear. At more abstract levels of discourse, removed from concrete experience, the process of reinforcement and correction does not work so efficiently. A term like "rabbit" is seldom ambiguous; a word like "merchant" enjoys no such advantage.148

Abstraction, like vagueness, can be a virtue. When a particular characteristic or characteristics are abstracted from the totality of divergent events, these dissimilar occurrences can be dealt with as a class. Abstraction produces a generality of reference. Legislation that seeks to specify the consequences of a range of human actions must necessarily deal in abstractions. The Code must speak in terms of "inventory" and "crops," not television sets and cotton plants.

The purposive interpreter does not seek to divine how the legislature would have decided the particular dispute before him; the legislature has not spoken in terms of a given contested case. He instead seeks to use a legislative statement of purpose-an abstract verbal formula-as a guide to how the policy making body would have him decide the dispute. Some process of translation is inevitable and reference to an articulated goal is, by its very nature, the preferred translation technique.

By identifying as desirable a specified outcome for a class of factually divergent events, a statement of purpose attempts to summarize what the more complex statutory message seeks to achieve. Thus, a statement of purpose may have a "plumb-line" effect, guiding the development of Code case law along a given policy line. ${ }^{149}$ For example, purposive interpretation of section 1-207 in Part II revealed that the provision is aimed at minimizing implicit waivers or elections by a party's conduct. ${ }^{150}$ On the basis of this underlying purpose, the interpreter might conclude that the section was not applicable to a reservation of rights on a payment in full check, which involves an attempt by express agreement to extinguish contractual rights.

To object to purposive interpretation because one is hesitant to extend a policy to a given case until exposed to its peculiar facts merely reflects that more than one policy frequently vie for imple-

148 This account draws on W. QUINE, WORD AND OBJECT 26-46 (1960) and A. Korzyssis, Science and SANTrY 371-85 (4th ed. 1958). See also Comment, A Computer Method for Legal Drafting Using Propositional Logic, 53 TErAs L. REv. 965, 971 (1975).

149 See R. Dias, JuRusprudence 222 (4th ed. 1976).

150 See text accompanying notes 127-32 supra. 
mentation.151 In those cases the "plumb-line" can function, as will be shown in Part IV, ${ }^{152}$ only if a priority among purposes is articulated. If an articulation of purpose is perceived as an abstract statement of a desirable goal rather than as a prediction that governs a given future case, "indeterminacy of aim" renders an unpersuasive objection to purposive interpretation. On the other hand, if the formulation of purpose is merely a statement at the same level of abstraction as the statutory text, and is subject to the same linguistic frailties, then it will seldom advance the process of interpretation. To see how this result can be avoided, it is necessary to examine the mechanics of purposive inquiry in terms of the insights of linguistic philosophy.

\section{The Mechanics of Purposive Interpretation}

\section{Semantic Ambiguity}

A purposive interpreter, realizing the limitations of language drawn from the insights of linguistic philosophy described above, ${ }^{153}$ starts with an appreciation of when translation is necessary. Whether Jones, a farmer who sells only his own produce, is a "merchant" or not will depend, in the first instance, on how the term "merchant" is defined. Among the options are these:

a. A merchant is someone who sells goods to earn his livelihood.

b. A merchant is someone who buys and sells goods to earn his livelihood.

c. A merchant is someone who has knowledge of the mercantile practices associated with the transactions in which he is engaged.

The question whether to classify Jones as a merchant is a problem of semantic ambgiuity, a problem of the meaning to be assigned to the words that trigger a legal formula or specify its consequences. ${ }^{154}$ Jones qualifies as a merchant under option a, but not under option $\mathrm{b}$; we would have to know more about Jones to decide whether he is

151 Hart has recognized this point. His objective in discussing "indeterminacy of aim" was to show that a judicial decision to extend policy cannot be mechanically predetermined. See H. HART, supra note 1, at 125-32.

152 See text accompanying notes 205-09 infra.

153 See text accompanying notes 142-48 supra.

154 See Allen \& Caldwell, Modern Logic and Judicial Decision Making: A Sketch of One View, 28 Law \& Contemp. Prob. 213, 228 (1963). 
a merchant under option $c$. The purposive interpretation of section 2-201(2), outlined in Part II, solved this problem by selecting one of the options, (c), as the one effectuating the drafters' purpose of imposing mercantile obligations only on those knowledgeable about merchant's practices. ${ }^{165}$ This purpose, in relation to the case of farmer Jones, is less ambiguous than the word "merchant" standing alone.

A similar process occurred in Part II's discussion of a purposive interpretation of section 2-607, the notice of breach provision. ${ }^{156}$ "Notice of breach" may require:

a. Notice of the fact of non-conformity.

b. Notice that the buyer regards the seller as having failed to meet his duties under the contract.

Reference to the Comments to section 2-607(3)(a) reveal that the provision was designed, as were its predecessors, to encourage the settlement of sales disputes. This function can best be promoted by option $b$.

Purposive interpretation resolves problems of semantic ambiguity by selecting the meaning that will best effectuate the isolated purpose. This selection is useful because a statement of purpose tends to be formulated with reference to concrete needs, such as the seller's need to know that the buyer considers him to have breached the contract notwithstanding his acceptance of the goods. Thus, the formulated purpose tends to be more directly tied to the type of experience commonly encountered by lawyers. Purposive interpretation reduces the level of abstraction typically characteristic of the language of the Code standing alone.

\section{Syntactic Ambiguity}

When ambiguity exists not in the meaning of individual words or sets of words, but in how they are logically arranged in terms of their antecedents and consequences, the purposive interpreter is faced with a slightly different problem-that of syntactic ambiguity. ${ }^{167}$ Section 2-316(3), the warranty disclaimer provision, presents an example illustrating this problem. ${ }^{158}$ The provision starts with the words, "Notwithstanding subsection (2)," suggesting that what follows is a complete exception to the preceding subsection. Never-

155 See text accompanying notes 46-61 supra.

156 See text accompanying notes 100-06 supra.

157 See Allen \& Caldwell, supra note 154, at 228.

158 See text accompanying notes 73-84 supra. 
theless, the Maryland Court of Appeals in Fairchild Industries v. Maritime Air Service $L t d . .^{159}$ found that only a partial exception was intended. Subsection (2) requires two ingredients for effective disclaimer of the merchantability warranty: use of the word merchantability, and, in the case of a writing, conspicuous placement of the disclaimer. The Fairchild court concluded, in light of the recognized purpose of preventing surprise, that "Notwithstanding" was addressed to the first, but not the second ingredient. ${ }^{160}$ A close reading of the Comments revealed that the drafters did not design section 2-316(3)(a) as an independent category at all, but rather as an example of the way in which warranties could be disclaimed by trade usage under section 2-316(3)(c). ${ }^{161}$ The language of the Code itself does not reveal this design; it is hidden, just as the partial exception found by the Fairchild court was not apparent from an examination of the statutory text.

Either interpretation of section 2-316 may be correct; in any event it stands as an example of poor draftsmanship in which the intended logical connections were unnecessarily obscured. Yet ordinary prose cannot always be easily molded into a reasonably compact statement that evidences precisely the conditions and consequences of its application.

Consider the drafting of U.C.C. section 3-201. That section was intended to integrate several provisions of the Negotiable Instruments Law. ${ }^{162}$ Section 49 of the N.I.L. provided that transfer of an order instrument without indorsement "vests in the transferee such title as the transferor had therein." This provision was designed to overcome the common law notion that an assignee of a chose in action took only an equitable interest and not a legal title. Section 49 thus enabled a transferee without indorsement to sue on the instrument in his own name.163 The section was not designed to change the requirements of becoming a holder; it specified that negotiation did not occur until an indorsement was placed on the instrument. A second N.I.L. provision, section 58, contained a stipulation that "a holder who derives his title through a holder in due course . . . has all the rights of such former holder in respect of all parties prior to the latter." This language was designed to protect the market of a holder in due course (HDG) by sheltering the rights of a holder buying from him. Note that only a holder

159274 Md. 181, 333 A.2d 313 (1975).

160 See text accompanying notes 81-83 supra.

161 U.C.C. $\$ 2-316$, Comment 7; see note 82 supra.

162 UNIFORM NEGOTJABLE INSTRUMENTS LAW $\$ \$ 27,49,58$.

163 See W. Britton, BIILS aNd Notes $\$ 74$ (2d ed. 1961). 
was to be sheltered; a transferee without indorsement of order paper could not take advantage of the stipulation in section 58 .

The drafters of the Code determined to carry forward these rules, but thought they could simplify them. They generalized section 49 , talking in terms of "rights" rather than "title." Their fundamental proposition, stated in section 3-201(1), was that "[ $[$ ] ransfer of an instrument vests in the transferee such rights as the transferor has therein . . . ." The generalized language made it unnecessary to state separately the shelter formula of section 58 because a purchaser from an HDC would be sheltered under this fundamental proposition. The wording of section 3-201(1) standing alone, however, suggests a short-cut way of acquiring holder status not available under the pre-Code law. A transferee without indorsement of order paper might thereby succeed to the rights of his holder-transferor.

That this result was not intended is evidenced by section 3-201(3), carrying forward the rule of section 49 of the N.I.L. that "[n]egotiation takes effect only when the indorsement is made...." This reflects the policy denying the special advantages of HDC status to a person taking the instrument under irregular circumstances in which it lacks the indorsement necessary for negotiation. ${ }^{164}$ It would serve no practical purpose to include section 3-201(3) barring a transferee without indorsement from being a holder in his own right if a transferee without indorsement could be a holder based on the rights of his transferor under section 3-201(1).

Unfortunately, these rather complex relationships are not evident on the face of section 3-201, and the First Circuit Court of Appeals, in an early decision construing the provision, held that a transferee without indorsement could qualify as a holder based on the status of his transferor. ${ }^{105}$ Later, more purposive readings were not misled by the failure of the draftsmen to articulate that section 3-201(3) stands as a practical limitation on the sweeping language of section 3-201(1) in this complex situation. ${ }^{168}$

104 See U.C.C. $\$ 3-201$, Comment 7. A similar policy in regard to fictitious payees and impostors is expressed in U.C.C. \$3-405. Compare UNrForM NEgoTIABLE INSTRUMENTS LAW $\$ 9(3)$.

165 Bowling Green, Inc. v. State St. Bank \& Trust Co., 425 F.2d 81 (1st Cir. 1970). Commentators have criticized the decision. See Hawkland, Depository Banks as Holders in Due Course, 76 CoM. L.J. 124 (1971); Comment, Bowling Green: The Bank as a Holder in Due Course, 71 Coums. L. Rev. 302 (1971); 12 B.C. Invos. \& Com. L. Rev. 282 (1970).

168 United Overseas Bank v. Veneers, Inc., 375 F. Supp. 596 (D. Md. 1974); Security Pac. Nat'l Bank v. Chess, 58 Cal. App. 3d 555, 129 Cal. Rptr. 852 (1976); see also Cheshire Commercial Corp. v. Messier, 6 Conn. Cir. Ct. 542, 278 A.2d 413 (1971). 
Even apart from complex subject matter, syntactic ambiguity is difficult to avoid because ordinary English language connectives may be ambiguous in their logical implications. Words such as "if" in the statement, "If $X$, then $Y$," may involve only simple implication, in which case the absence of $X$ does not preclude the realization of $Y$ in another fashion. On the other hand, "if" may express the more complex idea of co-implication, that is, "If and only if $X$, then $Y . "$ If co-implication is intended, then $Y$ cannot be achieved without $X .{ }^{107}$ The problem posed by this logical distinction will be present whether a legislative rule is expressly stated as a hypothetical proposition in the form, "If $X$, then $Y$," or if it is reducible to that form without changing its meaning. Every provision of the Code leaves the interpreter with the question: "Can a negative inference be drawn from what the drafters said here?"

The language of the statute may be misleading as to whether the logical grammar of co-implication was intended. For example, one of the alternative privity of contract provisions of the Code reads:

A seller's warranty whether express or implied extends to any natural person who is in the family or household of his buyer or who is a guest in his home if it is reasonable to expect that such person may use, consume or be affected by the goods and who is injured in person by breach of the warranty. ....$^{168}$

This language taken alone leads to the conclusion that a person may gain the benefit of a seller's warranty only if he falls within the designated class of beneficiaries. That such a negative implication was not intended is learned from Comment 3 to section 2-318 which declares:

[This] alternative expressly includes as beneficiaries within its provisions the family, household and guests, of the purchaser. Beyond this, the section in this form is neutral and is not intended to enlarge or restrict the developing case law on whether the seller's warranties, given to his buyer who resells, extend to other persons in the distributive chain.

167 See Allen, Symbolic Logic: A Razor-Edged. Tool for Drafting and Interpreting Legal Documents, 66 YALE L.J. 833, 833-37, 840-42 (1957); Comment, supra note 148 , at $974-77$.

168 U.C.C. \$2-318, Alternative A. 
The drafters of the Code did not intend to preclude courts from extending warranty protection to an employee of the buyer, ${ }^{169}$ or from recognizing a buyer's right to sue a remote manufacturer, ${ }^{170}$ but their art was apparently not sufficient to codify an intention of simple implication in the text of this alternative.

Whatever the level of the draftsman's art, purposive interpretation can compensate for his limitations. It attacks the problem of syntactic ambiguity by looking at the message as a whole. Following the analysis of linguistic philosophy, it translates the "meaning unit" in its entirety, whether it is' a sentence or a set of provisions. A purposive interpreter will say: "Whatever section 2-316 requires it must be something that will prevent the buyer from being surprised by a disclaimer provision. If we can tell in the light of this manifested purpose that the draftsman did not express himself clearly, we are entitled to ignore his deficient syntax." We may reject the negative implication of the section by referring to the less abstract manifestation of the statement of purpose.171 When we speak of preventing the buyer from being surprised by a hidden disclaimer clause, we speak of concrete experiences.

A similar tendency is manifested when courts conclude that a construction surety need not comply with article 9 of the Code in order to have priority over the financier of a defaulted contractor with respect to contract retainages. The abstract text of the relevant Code provision reads: "[T]his Article applies . . . to any transaction (regardless of its form) which is intended to create a security interest in personal property . . . "172 A surety typically takes a written assignment of the contractor's contract rights in the project, and, hence, appears to be engaged in a security transaction. But courts have defined the purpose of article 9 as the regulation of financing, and have consistently held that a surety is not a financier. They uphold a surety's priority, however, not on the basis of his written assignment, but rather under the doctrine of equitable subrogation. ${ }^{173}$ Thus, the Code language, in spite of its apparent inclusiveness, has not been held to give rise to a negative inference that the equivalent of a security interest can only be established by compliance with article 9 . This conclusion is not readily apparent upon the face of statutory language using so abstract a concept as "any

169 See Salvador v. Atlantic Steel Boiler Co., 457 Pa. 24, 319 A.2d 903 (1974). 170 See Kassab v. Central Soya, 432 Pa. 217, 246 A.2d 848 (1968).

171 See text accompanying notes 147-52 supra.

172 U.C.C. $\$ 9-102(1)$.

173 E.g., National Shawmut Bank v. New Amsterdam Cas. Co., 411 F.2d 843 (Ist Cir. 1969). 
transaction . . . intended to create a security interest;" but reference to the activity of financing, made relevant by purposive interpretation, does support such a conclusion.

Of course, use of the purpose formula does not resolve all possibilities of ambiguity. For example, there is a question whether "financing" is involved when a cattle farmer sells his livestock to a meatpacker and receives the meatpacker's check for the purchase price. After some hesitancy, the Fifth Circuit has concluded that the cattle farmer is subject to article 9 rules even though he considers himself a "cash seller" rather than a financier. ${ }^{174}$ Purposive interpretation reduces the number of problems caused by ambiguity; it does not eliminate them.

\section{Vagueness}

Purposive interpretation is also responsive to the problem of vagueness, but it reduces this characteristic of language in a different fashion. Vagueness is inherent in section 3-406 of the Code, which precludes a person from asserting forgery or alteration of an instrument if "by his negligence" he has "substantially contribute[d]" to that forgery or alteration. The adverb "substantially" is an indication of intentional vagueness. ${ }^{175}$ In contrast with the phrase "in any way contributing" it can be expected to create a broader range of cases in which its applicability is doubtful. Apparently the drafters intended to impose the loss on the negligent person only when he was commercially responsible in light of the particular facts. ${ }^{176}$ Asking whether the drawer was negligent in a given instance, so that it could be said that he was commercially responsible, is less abstract an inquiry than a search for a substantial contribution. At this level of application, therefore, a purposive reading may assist the interpreter in resolving problems of vagueness. The

174 In re Samuels \& Co., 526 F.2d 1238 (5th Cir. 1976) (en banc). See McDonnell, The Floating Lienor as Good Faith Purchaser, 50 S. CAL. L. REv. 429 (1977).

175 See M. BLACK, supra note 145 , at 42 n.34.

176 See U.C.C. $\$ 3-406$, Comment 3 ("No attempt is made to define negligence which will contribute to an alteration. The question is left to the court or the jury upon the circumstances of the particular cases."). Courts faced with the construction of $\$ 3-406$ have tended to utilize the distinction in pre-Code case law between negligence that is a "direct and proximate cause" of the forgery or alteration, and mere "laxity in business practices" which would not preclude a drawer from asserting the forgery or alteration against a payor. In so doing they have participated in the second method of avoiding purposive interpretation, described at text accompanying notes 85-119 supra. See, e.g., Bagby v. Merrill Lynch, Pierce, Fenner \& Smith, Inc., 491 F.2d 192 (8th Cir. 1974); Gast v. American Cas. Co., 99 N.J. Super. 538, 240 A.2d 682 (1968); Gresham State Bank v. O \& K Constr. Co., 231 Ore. 106, 370 P.2d 726 (1962). 
most significant contribution that purposive interpretation makes to this kind of issue, however, is preserving the vagueness of the doctrinal formulation.

Even in cases in which the statutory provision is not calculated to achieve open-ended inquiry, however, purposive interpretation will not resolve all vagueness problems. For example, having determined that the Code's warranty disclaimer provisions are designed to protect buyers from hidden disclaimers, ${ }^{177}$ the purposive interpreter may still be unable to tell in a given case whether the language used is "hidden" or "conspicuous." Purposive interpretation helps the courts deal with problems of vagueness only in a certain, but significant, range of cases.

\section{Lexical Clarity}

As the preceding sections illustrate, Twining's suggestion that statutory text and purpose formulations stand on the same linguistic footing ${ }^{178}$ must be rejected. Because statements of purpose tend to be less abstract, they assist the interpreter with problems of ambiguity and vagueness that adhere in the Code text. This line of reasoning raises the question explored by Professor Hart ${ }^{179}$ whether linguistic indeterminacy is a precondition to purposive inquiry.

The application of the text of the Code to a specified fact situation is not always vague or ambiguous, and to this extent lexical clarity is possible. For example, under section 9-302 of the Code a financier must file a financing statement to perfect a non-possessory security interest in his debtor's inventory. If a financier simply posts a sign over the debtor's stock of goods, he has clearly failed to file a financing statement. The directive that a financing statement must be filed is sufficiently concrete to inform a financier that it cannot be satisfied by the act of posting a sign; there is no problem of ambiguity or vagueness. Suppose, however, that instead of posting a sign, a financier presents the required statement to the specified official only to have that official fail to index it properly. The directive of section 9-302 is no longer lexically clear with respect to this situation. For this reason the drafters had to explain even the concrete directive of section $9-302$ by stating in section $9-403(1)$ : "Presentation for filing of a financing statement and tender of the filing fee or acceptance of the statement by the filing officer constitutes filing under this Article." 
Even this added definition does not create complete lexical clarity because "constitutes" is syntactically ambiguous. It could mean either "are required for" or "are the only acts required for." Purposive readings of section 9-403 have established that the latter translation was intended.180 The language of sections 9-302 and 9-403 considered in light of these hypothetical problems is relatively concrete; but the application of less concrete statutory language to the same factual situations will probably be less clear. Counsel for the inventory financier who only posted a sign may argue, for instance, that the financier had gained "possession" of the property, and thus perfected his interest as a pledge under section 9-305. Gaining "possession" is not like "filing a financing statement," as any veteran of a first year property course is aware. Moreover "possession" cannot be translated as "control" because for some purposes under the language of law posting a sign is a means of asserting control over property. ${ }^{181}$

It is remarkable how easily lexical clarity may be eliminated by changes in either the legal standard or the factual situation. For example, General Motors, as a car manufacturer, would undoubtedly be regarded as a merchant for purposes of section 2-201(2) of the U.C.C. The application is much less clear if in the context of a given controversy General Motors is not engaged in the manufacture of cars but the raising of apples. ${ }^{182}$

Lexically clear applications of law are of considerable importance to the attorney who must guide his clients even when the limitations of language do not come into play, but they seldom solve the jurist's quandry. An advocate would litigate an identifiably plain application of law to fact only if he were ignorant of the legal rule, failed to share basic language conventions with his community, found himself in a desperate situation, or believed the statutory language, though lexically clear, not to reflect the legislative will. Identifiable lexical clarity is rare with respect to the pivotal issues of an appellate case because Hart's standard case stays in the law office. Even if a jurist believed he was confronted with such a case, verification of its presence would be difficult. Both ambiguity and vagueness are dependent upon the relationship of patterns of lan-

180 See In re Royal Electrotype Corp., 485 F.2d 394 (3d Cir. 1973); In re Fowler, 407 F. Supp. 799 (W.D. OkJa. 1975); In re May Lee Indus., Inc., 380 F. Supp. I (S.D.N.Y.), aff'd, 501 F.2d 1407 (2d Cir. 1974).

181 "Posting" laws, for example, operate to restrict access to land for such divergent purposes as hunting and parking. In the commercial law field some states allow posting to be used to give notice of consignments. See U.C.C. $\$ 2-326$ (3) (a).

182 See text accompanying notes 28-61 supra. 
guage to the given fact situation. The conventions of language usage are not precisely defined; nor is linguistics a subject about which the typical jurist can claim special expertise. These considerations suggest that the judge, simply as a matter of prudence, should never decide a case on the assumption that he can apply the statutory text with regard to linguistic convention alone.

\section{Legislative Misstatement}

Apart from the practical questions raised in the preceding section, even if lexical clarity exists, its presence is not sufficient to decide a controversy under the principles of purposive interpretation. A direct consequence of the methodology of purposive interpretation is that non-purposive statutory language or implications of language, even if lexically clear, may be disregarded by the interpreter. The possibility that the term "merchant" may mean only one who buys and sells as a livelihood can be disregarded once the Code drafter's policy of tying merchant status to expertise is perceived. The misleading connective "Notwithstanding section (2)" which introduces section 2-316(3) loses much of its force once the underlying principle of protecting the buyer from surprise is articulated. If it could be shown that the legislature had misspoken-had simply not said what it meant, even though it spoke clearly-would purposive interpretation treat this type of language deficiency any differently than ambiguity or vagueness?

Obviously, a case of this type will be rare because drafters do not typically use clear language without meaning what it expresses. Nevertheless, consider in this regard Barclays Bank D.C.O. v. Mercantile National Bank, ${ }^{183}$ in which an Atlanta bank (Mercantile National) confirmed a letter of credit issued by a non-banking corporation. The issue was whether such a confirmation was possible under article 5 of the Code in view of its definition of "confirming bank" in section 5-103, which reads: "A 'confirming bank' is a bank which engages either that it will itself honor a credit already issued by another bank or that such a credit will be honored by the issuer or a third bank." ${ }^{184}$ This definition, drawn to reflect the normal practice of banks in dealing with credits, appears to limit "confirming bank" to a bank confirming the credits of another bank, and the credit in Barclays Bank was not of that description. Accordingly, Mercantile National argued that it could not be liable under section 5-107(2) which states: "A confirming bank by confirming a credit

183481 F.2d 1224 (5th Cir. 1973), cert. dismissed, 414 U.S. 1139 (1974).

184 U.C.C. $\$ 5-103(1)$ (f) (emphasis supplied). 
becomes directly obligated on the credit to the extent of its confirmation ...."

There was no problem of semantic ambiguity or vagueness in this case, although it could have been treated as a problem of syntactic ambiguity. Sections 5-102(1)(f) and 5-107(2) could be read as making the simple implication: If a bank confirms the credit of another bank, then the confirming bank is itself liable on the letter of credit. Absent co-implication, the provisions could not be read as supporting the negative inference that only the credits of another bank may be confirmed. Thus, a court would be free apart from these provisions, to rule on its own that the confirmation of nonbank credits results in liability to the confirming bank.

The Fifth Circuit in Barclays Bank, however, did not wish to describe the liability of the bank as arising apart from the rules of article 5. Mercantile National also denied its liability on the grounds that its commitment was a guaranty not within the power of a national bank to make. ${ }^{185}$ A guaranty has been distinguished from a letter of credit in that the former does not involve direct liability. To avoid Mercantile National's guaranty argument the court chose to associate the bank's action as closely as possible with the usual, direct liability of a confirming bank under section 5-107(2). Hence it concluded that Mercantile's liability arose under that section of the Code in spite of its definition of a confirming bank. The court stated:

Mercantile fails to look beyond the words embodied in the definition of a confirming bank. It fails to ask the crucial question-what policy justification is there for holding that a bank cannot confirm the credit of a non-bank issuer and thereby incur the obligations which the Code imposes on a confirming bank? Mercantile would have us apply a rule without examining the reason for that rule. But in order to justify applying a particular rule of law to a given set of circumstances, the application of that rule must advance the policy which gave birth to the rule in the first instance. This concept, whether followed implicitly or explicitly, is fundamental to our system of jurisprudence, as well as, to a proper application of the Uniform Commercial Code.

We have endeavored to determine if indeed there is a good reason for us to hold that a bank cannot confirm the credit of a non-bank issuer. This inquiry was necessary because we recognize that the drafters of the U.C.C. did not choose their words lightly, and a court should not be quick 
to conclude that an apparent rule of the Code is either unwise or inapplicable. Our search for a sound policy reason to apply the definition of a confirming bank literally and to exclude from Code-governance anyone who does not fit neatly within it has been in vain however. There is no reason to conclude that a bank should be unable to confirm the credit of a non-bank issuer under the U.C.G. ${ }^{186}$

The court then found that underlying policies of both the Code and article 5 supported confirmation of non-bank credits. It pointed to the central objective of encouraging new commercial practices articulated in section 1-102(2)(b) ${ }^{187}$ and the declaration in section 5-102(3) that article 5 is not intended as an exhaustive treatment of the concept of letters of credit. ${ }^{188}$ In short, it found that in light of its only operative purpose the definition of a confirming bank was over-specified, and that the over-specification could be disregarded. It denied operative force to the Code language just as if it were a simple, but clear, slip of the legislative pen.

The Barclay Bank opinion demonstrates how a court dedicated to purposive interpretation would approach legislative misstatement. The opinion held that the words of a statute are not sacred in themselves, but are entitled to respect only to the extent they embody a legislative purpose. This approach would improve the whole process of statutory interpretation by preventing a judge from dodging purposive inquiry on the grounds that his case is lexically clear. $\mathrm{He}$ would still be required to confirm that the "clear" language is purposive. The approach would also make it more difficult for a judge to attribute a result to the legislature when that body has not adopted a policy compelling that result. ${ }^{139}$

An objection may be raised at this point that purposive interpretation knows no limits. If the "art of proliferating a purpose" 190 is not controlled by clear legislative text, what are its limits? How far can the courts go in disregarding literal language that the legis-

186481 F.2d at 1230.

187 Id.

188 Id. 1231. Section 5-102(3) also states: "The fact that this Article states a rule does not by itself require, imply or negate application of the same or a converse rule to a situation not provided for or to a person not specified by this Article."

189 For example, courts in Georgia and Maryland have refused to extend article 2 warranty provisions to certain bailments and leases because the text of the article deals with "sales." See Mays v. Citizens \& S. Nat'l Bank, 132 Ga. App. 602, 208 S.E.2d 614 (1974); Bona v. Graefe, 264 Md. 69, 285 A.2d 607 (1972). Comment 2 to $\$ 2-313$, however, expressly states that no such policy restriction was intended. 190 The term was created by Judge Learned Hand in Brooklyn Nat'l Corp. v. Commissioner, 157 F.2d 450, 451 (2d Cir.), cert. denied, 329 U.S. 733 (1946). 
lature, as the chief policy making body within a democratic system, has declared to be the law?

\section{The Limits of Purposive Interpretation}

Advocates of purposive interpretation who insist that linguistic convention is itself insufficient to limit an articulated purpose have experienced difficulty in defining what those limits are. The problem troubled Professor Fuller who, in making it concrete, supposed a criminal statute declaring: "The sale of absinthe shall be unlawful." The purpose of this enactment was stipulated to be the protection of public health. What is there, Fuller asked, to prevent a judge from saying: "Now, as everyone knows, absinthe is a sound, wholesome, and beneficial beverage. Therefore, interpreting the statute in the light of its purpose, $I$ construe it to direct a general sale and consumption of that most healthful of beverages, absinthe." 191 As a purposive interpreter, a judge cannot rest with the common meaning of the terms of the prohibition. Fuller, admitting that his explanation lacked clarity, attempted to resolve the difficulty by saying that every statute has a "structure" that is either explicit in the enactment itself or exists by virtue of its relationship to other laws; therefore a construction of the absinthe prohibition statute that nonetheless permitted the sale of absinthe would violate its structural integrity. ${ }^{192}$ Under Fuller's analysis "structure," a separate entity, rather than linguistic convention, limits the extent to which purpose may be promoted by the court.

The restraining force in this type of case need not be viewed as distinct from legislative purpose. The methodology of purposive interpretation outlined in this Article would take the interpreter beyond the generalized formulation of the act that recognized its intention to protect the public health. Concentrating first on the language of the enactment, the purposive interpreter would note its specificity. The legislature did not prohibit the sale of dangerous drugs; it prohibited the sale of absinthe. This specificity suggests that the legislature made the factual determination that absinthe is harmful and that it has, in effect, adopted a sub-policy of precluding any contest in the courts about the healthiness of absinthe. A review of the legislative history of the absinthe prohibition statute would, in all probability, confirm the adoption of this specific subpolicy. Certainly such a purpose would be articulated in any commentary accompanying the enactment.

191 Fuller, supra note 10, at 670.

$192 I d$. 
A similar analysis can be made of Code provisions. For example, section 9-301(1)(b) states that "an unperfected security interest is subordinate to the rights of . . . a person who becomes a lien creditor before the security interest is perfected." The purpose of the perfection requirement is to protect third parties who might otherwise rely on apparently unencumbered assets in the hands of the debtor. Perfection, whether by public filing or by the secured party taking possession, ${ }^{193}$ gives public notice of the security interest. Nevertheless, the legislative text is specific; it protects any "lien creditor," not just "creditors who rely on apparently unencumbered assets." A financier who fails to perfect cannot argue that he should prevail against a particular lien creditor because that lien creditor in dealing with the debtor did not rely on apparently clear assets. Even a lien creditor who knew of the unperfected security interest when he extended credit is entitled to protection. The provision implements a sub-policy of precluding contests about whether a particular lien creditor so relied, in order to avoid evidentiary diffculties with respect to that issue. ${ }^{194}$

There is a danger that the general objective will be pictured as an ultimate end that exerts no decisional restraints beyond those embodied in the means or subpolicy, while the means, equated with the statutory text, will be viewed as a rigid prescription that must always be followed. The theory of purposive interpretation rejects both of these propositions. Legislative purpose, whether expressed generally or specifically, is entitled to be implemented (or "promoted," to use the Code's word ${ }^{195}$ ) unless it conflicts with another purpose adopted by the legislature, or otherwise recognized by law, that is entitled to priority.

Although the policy of protecting parties from secret security interests might be extended so as to subordinate unperfected security interests to claimants who are not lien creditors, the proviso of section 9-201 that "a security agreement is effective according to its terms," "except as otherwise provided by this Act" 196 cuts against such an extension. The policy of effectuating security arrangements

193 See U.C.C. $\$ \$ 9-302,9-305$.

194 See Comment, Security Interests Under Pledge Agreements, 51 YALE L.J. $431,446-47$ (1942).

195 See U.C.C. $\$ 1-102(1)$; text accompanying note 21 supra.

196 For an example of purposive interpretation which, in the absence of a countervailing policy, carries a Code policy beyond the statutory text, see Riley v. Miller, 549 S.W.2d 314, 316 (Ky. 1977) (financing statement without addresses effective under $\$ 9-402$ where all concerned know location of debtor and secured party). 
agreed to by a debtor and financier limits the policy of protecting against secret liens. Only those categories of claims listed in section 9-301 are entitled to priority over unperfected interests. Furthermore, as another component which purposive interpretation must consider, those categories are themselves subject to qualification as a result of external policies that underlie the Code. If, for example, a lien creditor, before extending financing to the common debtor, not only learned of an existing unperfected security interest but also told the secured financier not to worry about filing a financing statement, a concept such as "estoppel" would be used to deny the lien creditor priority. The seemingly absolute subordination of unperfected security interests to lien claims might no longer obtain.

This process of limiting a statutory purpose by reference to other objectives recognized by the legal system is illustrated by the decision in General Insurance Co. v. Lowry, ${ }^{197}$ which involved another article 9 priority rule. Under section 9-312(5) of the 1962 Code, security interests that were not all perfected by filing were ranked in chronological order of perfection, assuming that more specific priority rules stated in the Code were not applicable. The general rule was to grant priority to the holder of the first interest perfected even if he took his interest with knowledge of an existing unperfected claim in order to reward the diligent. ${ }^{198}$ In the Lowry case Lowry had executed notes granting a security interest in stock to General Insurance. Lowry also signed a memorandum promising that he would "do no act which will reduce or impair the security . . ." and would "cooperate in the preparation and execution of the instruments necessary to perfect the security." 190 Lowry's counsel in this transaction witnessed his client's signature on the memorandum promising cooperation in regard to the collateral. Although the security interest in the stock could only be perfected by delivery of the stock certificates to the insurance company, no such transfer occurred. Instead the shares were pledged to secure Lowry's debt to his attorney's law firm. By taking possession of the stock certificates the attorney perfected a security interest in the stock on behalf of his firm, and under section 9-312(5)(b) the law firm was entitled to priority over General Insurance, whose interest. was unperfected. The court felt, however, that there were "unusual circumstances" which in the name of "good faith" precluded this

197412 F. Supp. 12 (S.D. Ohio 1976).

198 U.C.C. $\$ 9-312(5)$ (b) (1962 version).

199412 F. Supp. at 13. 
result. ${ }^{200}$ In spite of the rule in section 9-312(5), it recognized an "equitable lien" granting priority to the insurance company. Although the court referred to the concept of good faith, it did not even cite the U.G.G. provision declaring that "[e]very contract or duty within this Act imposes an obligation of good faith in its performance or enforcement." 201 The court supported its holding by reference to the need to invoke its equitable powers "in narrowly-circumscribed situations," 202 a procedure it found to be consistent with the Code.

Cases like Lowry demonstrate the value of analyzing all legislative material in terms of purpose or policy. A legislative text, even a specific one, is never a complete statement, and is not intended to be. The legislature could not anticipate the facts of the Lowry case, but it could anticipate the possibility of fact situations arising in which according priority to the first perfected interest would be unfair or cause unnecessary hardship. A court might then find equitable relief consistent with section 9-312, recognizing that that section expressed a policy not intended to be absolute. Similar flexibility would exist in the case of a statute prohibiting the use of absinthe. If a defendant could show that consumption of absinthe was necessary to prevent him from going blind, the court would free him on a defense of necessity, even though the text of the legislation was silent concerning such a justification. ${ }^{203}$ Once the incompleteness of statutory formulas is appreciated, it can be understood why the courts grant relief in cases presenting particular equities or hardships. ${ }^{204}$

The crucial step in statutory interpretation under the Code and elsewhere frequently consists of determining which of two or more expressed policies are entitled to priority in a given factual context. The methodology of purposive interpretation is again helpful in determining that priority. The search for the intended priority begins with the language of the Code. In considering the status of farmers under section 2-201(2), two policies were discovered to be at work: minimizing one-sidedness in the operation of the

200 Id. 14.

201 U.C.C. \$ 1-203.

202412 F. Supp. at 14.

203 See United States v. Randall, 20 Crar. L. Rep. (BNA) 2299 (D.C. Super. Ct. 1976) (use of marijuana to treat glaucoma); Gardner, The Defense of Necessity and the Right to Escape From Prison-A Step Towards Incarceration Free From Sexual Assault, 49 S. CaI. L. Rev. 110 (1975).

204 Riggs v. Palmer, 115 N.Y. 506, 22 N.E. 188 (1889), which figures so prominently in Professor Dworkin's development of the role of principles, can be explained on this basis. See text accompanying notes 8-9 supra. 
Statute of Frauds by allowing a memo binding the sender to bind the receiver; and protecting those not knowledgeable about the merchant practice of answering inaccurate memos. ${ }^{205}$ The opening words of the section stating a rule that is to apply "Between merchants" suggests that the second policy has priority here, and that suggestion is confirmed in the commentary to section 2-104..$^{206}$

Similarly, the policy of effectuating security arrangements expressed in section 9-201 was found to prevent the extension of the policy disapproving secret security arrangements by benefitting those not expressly protected in section 9-301.207 The language of section 9-201 declaring security agreements to be effective according to their terms "except as otherwise provided by this Act" stands as an express statement of priority.

Likewise, the Lowry court, in subordinating the law firm that was first to perfect its security interest, might have pointed to the language of section 1-203 that "Every contract or duty within this Act imposes an obligation of good faith in its performance or enforcement." 208 Here the word "every" expresses the priority which the Code drafters accorded to the objective of protecting parties from those acting in bad faith.

In this last case, of course, the issue of priority is not difficult, and its resolution is not dependent on a manifestation of priority in the statutory language or the Comments. The conflicting policies before the Lowry court were rewarding the diligent and protecting the unsuspecting from misleading conduct. Once the court determined that the lawyer's conduct in Lowry amounted to bad faith, there was no doubt that the second policy would prevail. The deep institutional bias within those divisions of our legal system dealing with commercial matters against fraud or conduct approaching fraud would create a consensus on the predominant policy in Lowry even if the Code had not contained a good faith provision. Such institutional values may be regarded as the commercial law equivalent of the background factors, or "policies," which Dworkin suggested must be considered in projecting legislative purpose. ${ }^{209}$

There are occasions, however, when neither the technique of purposive interpretation nor recognized institutional priorities will provide an easy answer for selecting among several relevant statu-

205 See text accompanying notes 46-61 supra.

206 U.C.C. $\$ \$ 2-201(2), 2-104$, Comment 2.

207 See text accompanying note 196 supra.

208 See text accompanying notes 197-202 supra.

209 See note 2 supra. 
tory objectives. Consider the issue, presented in the American Card $^{210}$ case, whether a standard form financing statement may operate as a security agreement when there is only parol evidence that the parties intended it to have that effect. As noted in the earlier discussion, ${ }^{211}$ two policies are embodied in sections 9-203 and $9-105(1)(l)$ of the Code. The first is a desire to simplify the formal requisites for a security agreement in the interest of effectuating agreements actually made by the parties. The second is the evidentiary policy embodied in the requirement of a written agreement which "creates or provides for" a security interest. The courts have uniformly held that a financing statement standing alone is insufficient, ${ }^{212}$ but their decisions seem to be grounded on non-purposive readings of the language in section $9-105(l)$, "creates or provides for." The image extracted from this language is that it requires at least a diluted form of granting clause. ${ }^{213}$ Typically that image hinges on a dictionary translation of "provides for." 214 The Code language is sufficiently ambiguous, however, to include the possibility that a financing statement provides for a security interest if the parties so intend. The Comments to section 9-203 are also inconclusive on the dividing line between these policies. ${ }^{215}$ Indeed, the desired aim of the draftsmen of these sections is notably unclear. ${ }^{210}$

When the priority policy in relation to a contested situation is not disclosed by the Code's language, history, or commentary, the purposive interpreter faces a difficulty similar to that which he confronts when absolutely no policy is disclosed by those sources. He may seek guidance from the general underlying objectives stated in section $1-102,217$ but those objectives are stated with a generality that diminishes their usefulness. They may, in fact, also point in

210 American Card Co. v. H.M.H. Co., 97 R.I. 59, 196 A.2d 150 (1963).

211 See text accompanying notes 85-97 supra.

212 See Mitchell v. Shepherd Mall State Bank, 458 F.2d 700 (10th Cir. 1972); Mid-Eastern Elecs., Inc. v. First Nat'l Bank, 380 F.2d 355 (4th Cir. 1967); Needle v. Lasco Indus., Inc., 10 Cal. App. 3d 1105, 89 Cal. Rptr. 593 (1970).

213 See text accompanying notes $89-90$ supra.

214 Id.

215 In support of the simplification policy, see Comments 5 ("this Article reduces formal requisites to a minimum") and 4 (parol evidence may be used to show absolute conveyance intended for security). On the other hand, Comment 3 indicates that the requirement of a written record "minimizes the possibility of future dispute as to the terms of a security agreement ...," and another sentence within Comment 5 characterizes the provision as "in the" nature of a Statute of Frauds."

216 Professor Gilmore has confessed, for example, that he sees no justification for different sets of requisites for a security agreement (U.C.C. $\$ 9-203$ ) and a financing statement (U.C.C. $\$ 9-402$ ). 1 G. GrMorE, supra note 109 , at $\$ 11.4$. 217 See text accompanying note 20 supra. 
different directions. A court faced with the problem of the financing statement as security agreement today would have to contend with the policy of simplification in section 1-102(2)(a), which supports the recognition of a financing statement as a security agreement, and the policy of uniformity in section 1-102(2)(c), which, in light of the case law, supports the contrary result. Moreover, how is the jurist to assess which alternative will modernize the law governing commercial transactions in accordance with section 1-102 (2)(a)? Will not his assessment of the consequences of each construction become more significant as the inquiry into legislative purpose becomes more speculative?

Nor is this the kind of case in which background institutional priorities of the type noted in Lowry provide a persuasive reason for holding that the simplification or evidentiary policy should control. The competing institutional values here are the desire to effectuate the intended agreement of the parties, on the one hand, and the need for certainty in regard to important commercial transactions, on the other. Our system does not accord an obvious priority to either of these values, just as their priority with respect to this case is evidenced by neither the Code, its commentary, nor its history. From the standpoint of the purposive interpreter, he faces a "Hard Code Case"-not because of the presence of linguistic indeterminacy, but because of his inability to resolve the indeterminacy by using the methodology of purposive interpretation. ${ }^{218}$ Consistency with the realism of his forebears requires the purposive interpreter to admit at this point that his methodology is inadequate to restrain his judgment. The courts have not acknowledged this inherent difficulty present within the financing statement as security agreement issue, ${ }^{219}$ but have reflexively preferred the value of evidentiary certainty to simplification, ${ }^{220}$ and held the

218 Professor Soper gives a similar definition of a hard case. See Soper, supra note 12, at 486-88. He also advocates the recognition of "judicial technique principles" which are not to be considered "law" but rather are implicit in the concept of judging. Id. 490-92. If Soper's "judicial technique principles" were extended to embrace the attitudes required for judging in a democratic society which recognizes legislative supremacy, then the methodology of purposive interpretation would qualify for inclusion in this category.

219 E.g., In re Mann, 318 F. Supp. 32 (W.D. Va. 1970); Crete State Bank v. Lauhoff Grain Co., 195 Neb. 605, 239 N.W.2d 789 (1976).

220 The non-purposive cases in this area frequently rely on Safe Deposit Bank \& Trust Co. v. Berman, 393 F.2d 401 (1st Cir. 1968), which held that a security agreement limited to a specific note could not be amended by subsequent notes to cover new advances. The court stated:

To the extent that the legal significance of documents may be varied and enlarged by other documents evidencing an understanding of the immediate parties to a transaction, we suspect that the law of commercial 
financing statement alone to be insufficient. In so doing, they have not been implementing a legislative policy, but fashioning one of their own. 221

\section{Gonclusion: The Technigue and Its Implications}

Part of this Article has been devoted to showing how the methodology of purposive interpretation has either been disregarded or used in the construction of the Uniform Commercial Code. Examples were given illustrating how courts use such devices as the plain meaning rule, the pre-Code formula, and the summary statement of authorities to effectuate their own policies in opposition to those of the Code drafters. In contrast to these methods of surreptitious judicial legislation, the method of purposive interpretation was outlined, involving the following steps:

1. Start with the statutory language and read it all as it stands with an eye to the underlying purpose or purposes and the relationship between them.

2. Look for articulation of purpose in the Official Comments.

3. Explore how the present statutory text varies from earlier drafts of the Code and from the treatment of the same subject in pre-Code law.

transactions will not achieve the stated purposes. The basis of the trouble here is that appellee used an inappropriate form to do what it apparently wished. It not only chose to prop up its inadequate security agreement with a narrative recitation on a note of the same date but persisted on at least four other occasions in doing the same thing.

In a commercial world dependent upon the necessity to rely upon documents meaning what they say, the explicit recitals on forms, without requiring for their correct interpretation other documents not referred to, would seem to be a dominant consideration. If security agreements which on their face served as collateral for specific loans could be converted into open-ended security arrangements for future liabilities by recitals in subsequent notes, much needless uncertainty would be introduced into modern commercial law. In effect, notes would take on the character of security agreements.

Id. 404. It should be noted that the need for certainty treated by the court as the "dominant consideration" is not listed as one of the Code's underlying purposes and policies in $\$ 1-102$.

221 The limitations on purposive interpretation which are developed here are those implicit in the rationale of the theory itself. Additional restraints on the technique arise from other sources. For example, purposive interpretation would not be controlling in a case in which the statute to be construed was unconstitutional. In addition, it has been suggested that on the basis of institutional considerations, courts are entitled to particularly unequivocal expressions of legislative purpose with respect to politically sensitive questions. See Wellington \& Albert, Statutory Interpretation and the Political Process: A Comment on Sinclair v. Atkinson, 72 YALE L.J. 1547 (1963). Such questions are not often presented in Code litigation. 
4. After considering statutory language, Official Comments, and historic context, in seriatum, examine these factors in combination for a coherent interpretation.

Purposive interpretation is not a license to be casual with the language chosen by the legislature. It recognizes instead that legislating is a complex and specialized act of speaking that cannot be analogized to the simple command of parent to child. Democratic values according priority to the legislature as the primary policy making body are more likely to be effectuated if legislative pronouncements are read in a way which takes into account the linguistic problems faced by draftsmen. Experience with the technique of purposive interpretation under the Code shows:

1. Legislative purpose can be articulated in a manner that will control the decision in a significant range of cases. By reducing linguistic problems of ambiguity and vagueness, the technique of purposive interpretation can yield the one correct result in those cases. Purposive interpretation can only reduce linguistic indeterminacy, however; it cannot eliminate it. No matter how skillful the articulation of purpose by the drafters, cases will arise in which resolution is doubtful even in light of the purpose of the relevant statutory provisions.

2. When legislative purpose has been articulated, it must always be given due consideration. Hart's suggestion that some standard cases may be decided in light of linguistic convention alone must be rejected. ${ }^{222}$ Although lexical clarity is possible with respect to a given fact situation, it is not sufficient itself to dictate a decision. Purposive interpretation not only guides the jurist through linguistic problems of ambiguity and vagueness, but also ameliorates limitations on the draftsman's art. Reference to purpose guards against the comparatively rare hazard of simple legislative misstatement. More importantly, it alerts the judge to the incompleteness of the legislative text, that is, its typical failure to expressly exclude unusual cases in which application of the particular policy would be unfair or cause unnecessary hardship. Approaching the text from the baseline of its purpose opens the way to barring its application in those cases. This countervailing "escape-valve" policy of relieving hardship can be allowed to control the legislative purpose expressed in a particular section of the Code. 
3. For similar reasons, Dworkin's model, in which legislative policy is limited by the canonical text of the statute, must also be rejected by the purposive interpreter because it does not allow for the correction of misstatement, for the promotion of legislative policy in the absence of countervailing policies, or for the balancing of conflicting policies. A court's decision is restrained not by Code language itself but by the policies and priorities it expresses. When the draftsmen have articulated their goal and its priority with relation to other objectives, purposive interpretation is available to preserve the interpretation process as a contest about "what rights the legislature has already created." ${ }^{223}$ Draftsmen are not perfect, however, and they cannot always meet the needs of the purposive interpreter. Moreover, even when those needs are met, the latent ambiguity and vagueness of the formulation of purpose leads to other cases that cannot be resolved under the purposive technique. A "Hard Code Case" is one that cannot be resolved by purposive interpretation. Such cases are contests not about what the legislature has done but about the consequences, including general social effects, of construing legislation in alternative ways.

At the level of the "Hard Code Case" the role of the judge as lawmaker begins. Accordingly, experience under the Code gives theoretical support to the positivist view that judicial legislation is inevitable. At the same time, the range of cases that can be controlled by purposive interpretation-including many cases thought to present difficult and important U.G.C. problems-lends practical encouragement to those who seek to minimize judicial legislation. The "rights thesis" 224 may be, as Hart has termed it, a "Noble Dream," ${ }^{225}$ but it expresses an ideal worth seeking, and one which we are capable of achieving, at least in part.

223 Dworkin, supra note 2, at 1088 n.23.

224 Id. 1058-60.

225 Hart, supra note 1. 